\title{
The new era of nanotechnology, an alternative to change cancer treatment
}

\author{
This article was published in the following Dove Press journal: \\ Drug Design, Development and Therapy \\ 27 September 2017 \\ Number of times this article has been viewed
}

\begin{abstract}
Ancuta Jurj'
Cornelia Braicu'

Laura-Ancuta Pop'

Ciprian Tomuleasa ${ }^{1,2}$

Claudia Diana Gherman 3,4

loana Berindan-Neagoe ${ }^{1,5,6}$
\end{abstract}

'Research Center for Functional Genomics, Biomedicine and

Translational Medicine, University

of Medicine and Pharmacy "Iuliu-

Hatieganu”, Cluj-Napoca, Romania;

2Department of Hematology,

The Oncology Institute "Prof Dr lon

Chiricuta", Cluj-Napoca, Romania;

${ }^{3}$ Practical Abilities, Department

of Medical Education, University

of Medicine and Pharmacy "Iuliu-

Hatieganu", Cluj-Napoca, Romania;

${ }^{4}$ Department of Medical Education,

University of Medicine and Pharmacy

"Iuliu Hatieganu", Cluj-Napoca,

Romania; ${ }^{5}$ Department of Functional

Genomics and Experimental Pathology,

The Oncology Institute "Prof Dr lon

Chiricuta”, Cluj-Napoca, Romania;

"MedFuture Research Center for

Advanced Medicine, University

of Medicine and Pharmacy "Iuliu-

Hatieganu”, Cluj-Napoca, Romania

Correspondence: Claudia Diana

Gherman

Department of Surgery, "luliu Hațieganu"

University of Medicine and Pharmacy,

23 Marinescu Street, 400337

Cluj-Napoca, Romania

Email gherman.claudia@umfcluj.ro
Abstract: In the last few years, nanostructures have gained considerable interest for the safe delivery of therapeutic agents. Several therapeutic approaches have been reported, such as molecular diagnosis, disease detection, nanoscale immunotherapy and anticancer drug delivery that could be integrated into clinical use. The current paper aims to highlight the background that supports the use of nanoparticles conjugated with different types of therapeutic agents, applicable in targeted therapy and cancer research, with a special emphasis on hematological malignancies. A particular key point is the functional characterization of nonviral delivery systems, such as gold nanoparticles, liposomes and dendrimers. The paper also presents relevant published data related to microRNA and RNA interference delivery using nanoparticles in cancer therapy.

Keywords: nanotechnology, gold nanoparticles, liposomes, dendrimers, microRNA, RNA interference

\section{Introduction}

Malignant cells are resistant to the anticancer action of chemotherapeutic agents and cell division inhibitors, which reflects their ability to change at molecular level and develop tumor survival strategies that activate the angiogenic mechanism, in order to prevent hypoxic conditions and to support nutrient intake. Therefore, the main therapeutic approaches are targeting the hallmarks of cancer, particularly aiming to inhibit tumor angiogenesis. Multiple cellular processes related to apoptosis or cell proliferation lead to alterations in signaling pathways that are responsible for resistance to chemotherapy and drug tolerance in a cancer cell. ${ }^{1-3}$

The progress of nanotechnology-based screening techniques has led to targetbased drug development regimens which increase the survival rate of cancer patients. ${ }^{4}$ Therapeutic agents are becoming highly specific and have a high affinity for various molecular targets, depending on the malignancy's genotype and phenotype. ${ }^{5}$ Cancer treatment strategies include a wide range of combination chemotherapy drugs, in addition to radiotherapy and adjuvant/neo-adjuvant surgery. The main drawbacks related to chemotherapy are the unwanted side effects. Therefore, intensive research is carried out to develop novel therapeutic formulation using specific nanoparticles for targeted delivery in order to avoid the cytotoxic effects on healthy cells. ${ }^{6}$

Nanoparticle-based drug delivery systems show remarkable progress due to their ability to have a "controlled-release reservoir", which can safely deliver therapeutic agents to injury sites or specific cells. ${ }^{7,8}$ For safe use in medicine, nanoparticles must be biocompatible, that is, able to integrate within a biological system without causing immune response or negative side effects when the construct is directly released either into the tumor or into the bloodstream. ${ }^{9}$ Nanoparticles must also provide controlled 
drug release, increasing the therapeutic agent's protection and circulation time and thus decreasing toxicity to healthy cells. ${ }^{8,10}$ This can lead to enhanced permeability and retention (EPR) effect. ${ }^{11}$

Nanoparticles are used in medicine to improve bioavailability, ${ }^{12,13}$ to enhance the delivery of therapeutic agents ${ }^{14}$ or to develop novel imaging techniques, ${ }^{15-17}$ in order to assure the control of biological systems for single molecules or groups of molecules. ${ }^{18} \mathrm{~A}$ wide range of nanostructures such as liposomes, nano-diamonds, quantum dots, peptides, cyclodextrin, carbon nanotubes (CNTs), graphene and metal-based nanoparticles are used for diagnostic or therapeutic purposes (Figure 1). ${ }^{13}$ Nanoparticles are able to enhance the accumulation and release of pharmacologically active agents at the tumor site, improve therapeutic efficacy and decrease the intensity of side effects on the healthy tissues. Due to the intrinsic features of nanoparticles, it is possible to integrate both diagnostic and therapeutic agents into a single nanoparticle. These features allow monitoring the biodistribution and accumulation of agents at the target site, and thus, the release of drugs can be visualized and quantified, which may lead to proper assessment of their therapeutic efficiency. ${ }^{19,20}$

Low size of nanoparticles allows them to cross cellular membranes and avoid detection by the reticuloendothelial system, thus preventing their degradation. Their high surface area enhances the loading of therapeutic agents, making them ideal for medical purposes. ${ }^{21} \mathrm{~A}$ wide range of anticancer drugs such as rituximab, lestauritinib, carboplatin, paclitaxel, doxorubicin and tyrosine kinase inhibitors have been loaded onto nanoparticles with a potential effect against various cancers, and a superior therapeutic efficacy than free chemotherapeutics. $^{22-26}$

Due to the high incidence of death among cancer patients, there is an urgent demand for the development of novel and innovative delivery systems for therapeutic agents. For most cases, a single targeted therapeutic agent may not be sufficient, ${ }^{27}$ and therefore, nanoparticles are designed to assure an efficient delivery.

Our review paper summarizes the most recent data in the field of nanoparticle design and functionalization in the context of targeted and efficient therapy. The manuscript presents in a well-structured manner the newest developments in the field of nanotechnology, one of the most rising research niches from our times. Besides the basic strategies, we also discuss the latest forms of therapy involving nucleic acid delivery at targeted sites in the form of microRNA (miRNA) and small interfering RNA (siRNA). The present paper is also complemented by the comprehensive presentation of the chimeric antigen receptor (CAR) T cells therapy,

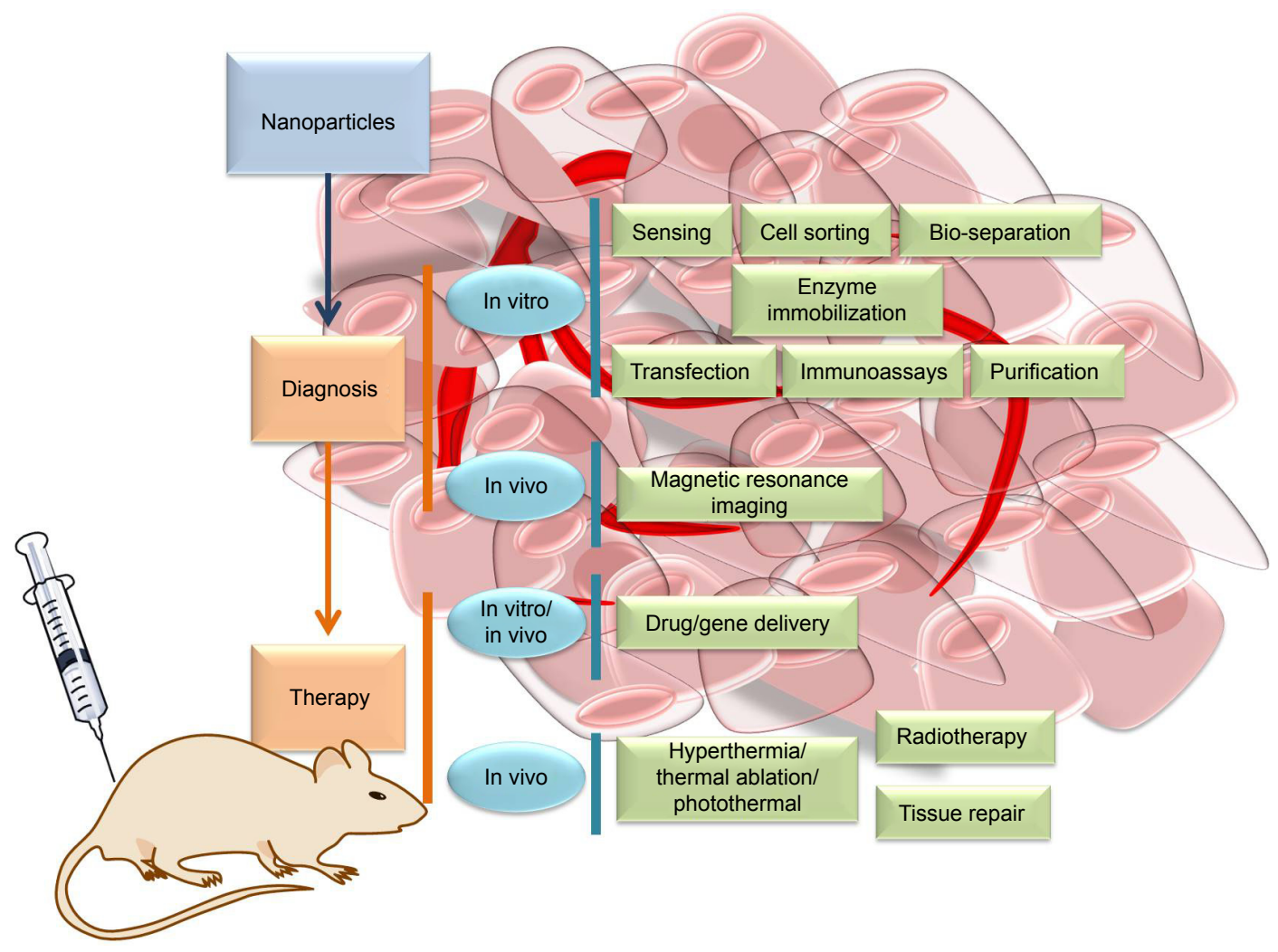

Figure I Different applications of nanoparticles involved in therapy and diagnosis. 
a novel domain with high-ranking chances of success in the clinical scenario. Therefore, we hope that this review will feed the need of both researchers and clinicians in the attempt to develop and implement superior forms of therapies for the benefit of patients. Moreover, the comprehensive presentation of the current achievements will stimulate the idea of hybrid nano-strategies that will combine their advantages of different therapies, minimizing at the same time the downsides associated with each type of therapy.

\section{Kinetics, biodistribution and release profile of nanoparticles}

The kinetics, biodistribution and release profile of the active compounds are modified by the nanodrug formulation, thus improving cancer treatment while enhancing EPR. To be more effective, the nanodrugs must be accumulated at the target tissues, for which the nanoparticles must be smaller than the mean pore size of the vasculature of the target tissues.

Nanodrugs are complex, and scientists must understand their structure and physical and chemical characteristics, as well as the biological principles employed to attach or encapsulate the therapeutic agents. ${ }^{28}$ Drugs could be selectively targeted to tumors through "active targeting" by using a peptide or an antibody that specifically binds to a molecule that is selectively expressed on targeted cancer cells. Drugs should "passively target" cell-specific functions or local environments in order to facilitate the uptake and accumulation in tumor tissues and inflammatory sites (Figure 2). ${ }^{29}$ In addition, there are some nanoparticle properties that determine their in vivo distribution, such as particle size, charge, core, surface properties, shape, flexibility, multivalence and controlled synthesis.

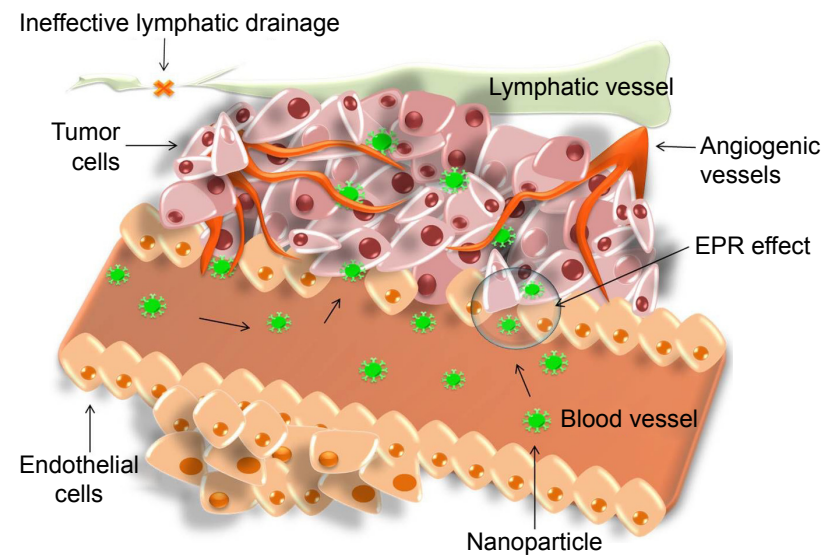

Figure 2 Passive targeting relies on cell-specific functions or local environments specific to target the tissue to facilitate uptake and accumulation in tumor tissues and inflammatory sites.

Abbreviation: EPR, enhanced permeability and retention.
Key areas of investigation in nanoparticle research are the pharmacokinetics and biodistribution, related to the nanoparticle size and its behavior. It was shown that the optimal size for the drug delivery systems is between 1 and $100 \mathrm{~nm}$. Small nanoparticles increasingly accumulate and penetrate into tumor tissues through the EPR effect, with elimination in the spleen being avoided. Multivalence is characterized by a high surface area-to-volume ratio, which offers high loading capacity for different imaging agents, targeting ligands and therapeutic agents. The shape of nanoparticles influences their internalization into cells, determining the in vivo behavior and biological function (Figure 3). To improve or reduce circulation time, the surface and charge of the nanoparticles can be changed; positive charge is correlated with a higher rate of nonspecific internalization and a shorter blood circulation time, when compared to negative and neutral charges. ${ }^{19}$

An important mechanism by which therapeutic agents are uptaken by the cells is the endocytic pathway. After passing through the cellular membrane, these agents are entrapped in endosomes and are degraded in lysosomes by specific enzymes. The main advantage of this mechanism is that it facilitates the endosomal escape and ensures cytosolic delivery of the agents, which helps achieving an effective biological-based therapy.

There are various mechanisms for endosomal escape that facilitate the release of the therapeutic agents into the cytosol. Pore formation occurs through the interactions between the membrane tension that extends the pores and the line tension that closes the pores. This causes the forming of pores

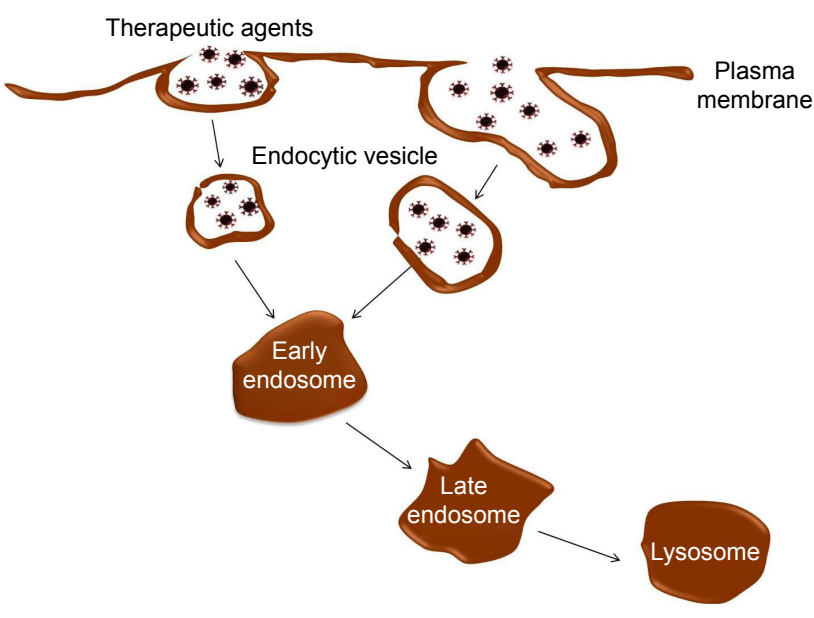

Figure 3 Nanoparticles internalization. Nanoparticles enter the cell via endocytosis, which is the main pathway for crossing the cellular membrane. Also, nanoparticles are internalized into the cells, and the cargo is released inside. Nanoparticles administered are cleared in the liver and spleen, which remain in these organs for a long time and are then uptaken by macrophages. Then, the nanoparticles exit the cell via exocytosis. 
in the lipid bilayer mediated by aggregates of peptides that enter into the membrane in a perpendicular orientation, thus leading to an inward curving of the membrane. The proton sponge effect (pH-buffering effect) is a mechanism caused by the ability of agents to inflate when protonated. Through this step, called "protonation", the entrapped components are released due to the inflow of ions and water into the endosomal environment, leading to endosomal membrane ruptures. Another mechanism is represented by the fusogenic peptides that have the ability to destabilize the endosomal membrane, which plays an important role in cellular trafficking and endocytosis. Endosomal membrane can be destroyed photochemically, by exposure to light. This method induces the formation of reactive singlet oxygen with a short lifetime which destroys the endosomal membrane, allowing the therapeutic agent to be delivered to the cytosol. ${ }^{30}$

A nanoparticle's intracellular fate is based on the selected endocytic pathway. However, many researches showed that the transport pathway can be affected by the physicochemical characteristics of nanoparticles, such as size, charge, shape, different endocytic machineries in various cell types, ${ }^{31}$ aggregation state and surface chemistry. ${ }^{32}$ Peñaloza et al showed that nanoparticles can be taken by recycling endosomes back to the extracellular environment, or may be degraded in lysosomes or trapped in an organelle, without releasing their content at the desired site..$^{13,33}$

\section{Delivery systems used in cancer research}

This section highlights the ideal delivery systems used in cancer therapy, such as vectors, gold nanoparticles, liposomes, hybrid systems, dendrimers and CNTs. The main purpose of this section is to describe delivery systems' designs, and to present their benefits and effects in the medical field. Novel nanoparticles that can target multiple altered mechanisms represent an important tool in cancer treatment and can be employed in viral and nonviral delivery systems, ${ }^{34}$ each of which has its specific advantages and disadvantages (Table 1).

The optimal way to deliver gene therapy is by direct administration of the therapeutic gene to the target site. However, this is extremely inefficient, unreliable and feasible only in tumors. Generally, in gene therapy approaches, the genetic material is delivered via the intravenous route; as nucleic acids are susceptible to degradation by nucleases and rapid clearance in systemic circulation, ${ }^{28}$ a vector is required to pack, protect and transport the genetic material to its site of action.

\section{Viral delivery systems}

Viral vectors are viruses capable of delivering genetic material into specific cells with the purpose of increasing gene expression or inhibiting the production of a target protein..$^{35,36}$ Among the viral vectors used for gene delivery are adenoviruses, retroviruses and lentiviruses. ${ }^{34}$ Viral vectors are efficient in gene delivery and expression, but their drawbacks, such as low transgenic size, high cost,$^{34}$ immunogenicity, oncogenicity ${ }^{35}$ and toxicity, ${ }^{36}$ limit their use. Retroviruses can be used for miRNA delivery inside somatic and germline cells. These types of viral vectors belong to RNA virus family, and their size is between 7 and $11 \mathrm{~kb}$. The cargo is delivered and integrated inside the target cell's genomic DNA during the mitotic phase of the cell cycle, infecting just the dividing cell. Lentiviruses belong to the retrovirus family and incorporate the foreign genetic material inside the host genome. These viruses are able to affect both dividing and nondividing cells through infecting postmitotic and terminal differentiated cells. Lentiviruses exhibit a high transfection efficiency and long-term stable expression. Adenoviruses contain double-stranded DNA (dsDNA) and are specific for miRNA gene delivery. Similar to lentiviruses, adenoviruses infect both dividing and nondividing cells. ${ }^{37}$ In addition, several tests employ adeno-associated virus-mediated gene delivery, which has the advantage to overcome resistance to conventional anticancer therapies ${ }^{38,40}$ and lead to a cell differentiation inhibition. ${ }^{39}$

\section{Nonviral delivery systems}

The alternative vectors available for drug delivery are nonviral vectors. Due to their cationic charge, these nanostructures interact with negatively charged DNA or RNA structures through electrostatic interactions obtaining cationic polymers (polyplexes) and cationic lipids (lipoplexes) (Figure 4). ${ }^{35}$ Cationic polymers are completely soluble in water and do not contain a hydrophobic moiety. They can be synthesized with different functional groups that are attached by substitution or addition, in different lengths and with different geometry. Cationic lipids are amphiphilic molecules that contain positive charges. Through the positive charge, lipoplexes are bound to a hydrophobic domain including two alkyl chains. This charge is associated with an amine group with different degrees of substitution, that is, amidine, guanidium and pyridinium. Cationic polymers differ from cationic lipids in some properties such as chemical structures, nucleic acid interactions and their behavior inside the cell. ${ }^{39}$ Nonviral vectors can be delivered through physical as well as chemical methods. When delivered through physical methods, the 
Table I Examples of therapeutic nanoparticles conjugated with different types of molecules

\begin{tabular}{lll}
\hline $\begin{array}{l}\text { Nanoparticle } \\
\text { type }\end{array}$ & Size & $\begin{array}{l}\text { Molecules used for } \\
\text { nanoparticles conjugation }\end{array}$ \\
\hline $\begin{array}{l}\text { Polymer gold } \\
\text { nanoparticles }\end{array}$ & $2-10 \mathrm{~nm}$ & Small molecule (curcumin) \\
$\begin{array}{l}\text { Gold } \\
\text { nanoparticles }\end{array}$ & $4 \mathrm{~nm}$ & WGA-HRP \\
& $11.2 \mathrm{~nm}$ & miR-2I \\
& $12 \mathrm{~nm}$ & $\begin{array}{l}\text { Tyrosine-kinase (lestauritinib, } \\
\text { sorafenib and quizartinib) and FLT3 } \\
\text { inhibitors (lestauritinib, midostaurin, } \\
\text { sorafenib and quizartinib) } \\
\text { cmHsp70.I monoclonal antibody }\end{array}$
\end{tabular}

$50 \mathrm{~nm} \quad$ Doxorubicin

Oxaliplatin

Platinum (IV) (cisplatin, the active analog of $\mathrm{Pt}[\mathrm{IV}]$ prodrugs)

Cationic arginine- $\quad 179 \pm 8 \mathrm{~nm} \quad$ siRNA

functionalized

gold nanoparticles

Liposomes $\quad 80-100 \mathrm{~nm}$

$90-100 \mathrm{~nm}$

Anti-HER2 monoclonal antibody fragments, doxorubicin

$\sim 100 \mathrm{~nm} \quad$ Folate, doxorubicin

$100 \mathrm{~nm}$

Nucleosome-specific monoclonal antibody $2 \mathrm{C} 5$, doxorubicin
Advantages

Effective delivery and extended release; increased the binding capacity for small molecule; safe and nontoxic in in vitro test

Lower dose delivered at the target organ; this type of conjugated nanoparticles has the potential to eliminate unwanted side effects by requiring a smaller effective dose Targeted BCL-2 genes and c-Met protein levels, increased apoptosis and diminished proliferation of glioma cells Inhibition of BCR-ABL and FLT3 genes

Disadvantages

Insolubility of small molecule under aqueous condition and low internalization rate ${ }^{80,81}$ Side effects such as nausea and seizures, nonspecific biodistribution and neuronal hyperactivity ${ }^{82}$ Absence of significant adverse side effects and safe as delivery system ${ }^{83}$ Increased resistance to chemotherapy and higher risk for disease relapse ${ }^{22}$

Improved detection of tumors; in perinuclear No toxic effects at area, the aggregates with diameter concentrations lower than between I and $2 \mu \mathrm{m}$ are detected; effective $\quad \mathrm{I}-10 \mu \mathrm{g} / \mathrm{mL}^{84}$ accumulation at the tumor site; enhanced radiation therapy by increasing the rate of tumor cell death

Increased cellular uptake and cytotoxicity

Cardiotoxicity and towards the MDR and transported the drug myelosuppression ${ }^{85}$ across the blood-brain barrier Increased in vitro cytotoxicity after conjugation, and conjugated particles were efficiently uptaken Increased cytotoxic effects of the Pt(IV)AuNP complex and free active form of the drug (cisplatin)

High effective siRNA transfection strategy, and cytosolic delivery of siRNA avoiding endosomal sequestration; effective for in vitro applications Increased antitumor effect (nude mice with MDA-MB-468 breast cancer cell line overexpressing EGFR)

No selective toxicity

Kidney toxicity and irreversible nerve damage

No side effects ${ }^{86}$

Low tumor internalization rate for intravenous treatment, retrieved in interstitial space being degraded and unspecific drug release ${ }^{87}$

Enhanced antitumor effect and increased drug accumulation into the cancer cell line (nude mouse with HER-2 overexpressing Bt-474 breast cancer cell line) ${ }^{88}$ Increased antitumor effect (murine lung cancer)

Targeting efficiency of folate-linked vesicles was affected by the amount of folate-PEG-lipid; a higher molar fraction of folatePEG-lipid in folate-linked liposomes decreased liposome uptake into cells ${ }^{89}$ Enhanced cytotoxicity and increased drug Introduction of new side accumulation into the cancer cell line in vitro effects such as skin toxicity and in vivo (in murine breast or lung cancer) manifested as hand-foot syndrome and mucositis ${ }^{90,91}$ 
Table I (Continued)

\begin{tabular}{|c|c|c|c|c|}
\hline $\begin{array}{l}\text { Nanoparticle } \\
\text { type }\end{array}$ & Size & $\begin{array}{l}\text { Molecules used for } \\
\text { nanoparticles conjugation }\end{array}$ & Advantages & Disadvantages \\
\hline & $<200 \mathrm{~nm}$ & Thiolated herceptin, paclitaxel, taxol & $\begin{array}{l}\text { Enhanced cellular uptake in vitro and } \\
\text { antitumor effects in vivo against BT-474 } \\
\text { breast cancer cell line }\end{array}$ & $\begin{array}{l}\text { Side effects given by drugs; } \\
\text { due to PEGylation, PILs } \\
\text { exhibited a steric effect } \\
\text { that proved to be more } \\
\text { cytotoxic than taxol, PLs } \\
\text { and herceptin }{ }^{92}\end{array}$ \\
\hline \multirow[t]{3}{*}{ Dendrimers } & $17 \mathrm{~nm}$ & $\begin{array}{l}\text { Paclitaxel (paclitaxel-conjugated } \\
\text { generation } 5 \text { PAMAM dendrimers) }\end{array}$ & $\begin{array}{l}\text { Had the ability to stall mitosis in a } \\
\text { dividing cell }\end{array}$ & $\begin{array}{l}\text { Cytotoxicity was due } \\
\text { to paclitaxel-stabilizing } \\
\text { microtubules; necessity } \\
\text { for further careful } \\
\text { toxicity studies }^{93}\end{array}$ \\
\hline & $29.1 \pm 3.9 \mathrm{~nm}$ & $\begin{array}{l}\text { Trastuzumab - monoclonal } \\
\text { antibody in combination with } \\
\text { docetaxel }\end{array}$ & $\begin{array}{l}\text { Induced apoptosis and enhanced cellular } \\
\text { uptake; trastuzumab-conjugated dendrimers } \\
\text { caused lower hemolysis than plain } \\
\text { dendrimers }\end{array}$ & $\begin{array}{l}\text { Side effects: PAMAM } \\
\text { dendrimers caused } \\
\text { hemolysis because of their } \\
\text { cationic nature }^{94}\end{array}$ \\
\hline & $50-100 \mathrm{~nm}$ & $\begin{array}{l}\text { Doxorubicin-conjugated } \\
\text { dendrimer nanoparticles using } \\
\text { glycylphenylalanyl-leucylglycine } \\
\text { tetrapeptide (Gly-Phe-Leu-Gly, } \\
\text { GFLG) }\end{array}$ & $\begin{array}{l}\text { Improved anticancer activity, decreased } \\
\text { the growth inhibition and increased the } \\
\text { accumulation of dendrimers-conjugated } \\
\text { doxorubicin at the tumor site }\end{array}$ & $\begin{array}{l}\text { Side effects due to } \\
\text { doxorubicin and } \\
\text { accumulation of } \\
\text { dendrimers in the kidney, } \\
\text { liver and brain rather than } \\
\text { the solid tumor tissue }{ }^{95}\end{array}$ \\
\hline $\begin{array}{l}\text { Carbon } \\
\text { nanotubes }\end{array}$ & $200 \mathrm{~nm}$ & $\begin{array}{l}\text { Paclitaxel (multiwalled carbon } \\
\text { nanotubes functionalized with } \\
\text { hyperbranched poly citric acid and } \\
\text { paclitaxel) }\end{array}$ & Increased cell penetration & $\begin{array}{l}\text { Exhibited a higher } \\
\text { cytotoxic effect compared } \\
\text { with unconjugated } \\
\text { paclitaxel; accumulation } \\
\text { in internal organs, and } \\
\text { not safe } \\
\text { n7,96 }\end{array}$ \\
\hline $\begin{array}{l}\text { Single-walled } \\
\text { carbon nanotubes }\end{array}$ & $2-3 \mathrm{~nm}$ & Doxorubicin & $\begin{array}{l}\text { Loading of doxorubicin onto SWNTs } \\
\text { reduced the toxicity associated with free } \\
\text { drugs; doxorubicin is directly loaded on } \\
\text { the carbon nanotubes surface; stable drug } \\
\text { loading, significantly prolonged blood } \\
\text { circulation, less toxicity and increased tumor } \\
\text { uptake by the EPR effect }\end{array}$ & $\begin{array}{l}\text { Side effects due to the } \\
\text { free doxorubicin that } \\
\text { caused disruption of the } \\
\text { intestinal lining consistent } \\
\text { with gastrointestinal } \\
\text { mucositis, and complete } \\
\text { loss of columnar epithelial } \\
\text { cells at the tips of villi; } \\
\text { accumulation in internal } \\
\text { organs, and not safe }{ }^{77,97}\end{array}$ \\
\hline
\end{tabular}

Abbreviations: WGA-HRP, wheat germ agglutinin horse radish peroxidase; MDR, multidrug resistance; AuNP, gold nanoparticle; siRNA, small interfering RNA; PEG, polyethylene glycol; PILs, PEGylated immunoliposomes; PLs, PEGylated liposomes; PAMAM, polyamidoamine; SWNTs, single-walled carbon nanotubes; EPR, enhanced permeability and retention.

vector delivers the gene to the target by applying a physical force that increases the cell membrane permeability. These methods cause cell injuries and increase the apoptotic rate, but are unable to prevent nuclease cleavage. ${ }^{37}$ The physical methods used are electroporation, ultrasound, microinjection and hydrodynamic applications. Meanwhile, natural and synthetic viral vectors can be delivered through chemical methods to deliver the gene to the target. These delivery systems were developed to improve the ligand's ability to attach on the surface, or to be able to encapsulate and deliver foreign genetic materials into the specific cell type. The main advantages are represented by the low immunogenic response, capability to carry large inserts, selected modifications, ${ }^{34}$ easy synthesis and cell-/tissue-specific targeting. ${ }^{35}$ Viral and nonviral delivery systems have different features, which are detailed further. Due to their ability to transfer their genetic material into host cells, viral vectors present higher transfection efficiency. ${ }^{37,40}$ However, there are difficulties in large-scale production mainly due to the size of the carried DNA, mutagenesis, ${ }^{41}$ toxicity and immunogenicity, ${ }^{37}$ which limit the viral vectors progression. Nonviral vectors have the ability to deliver nucleic acids into cells, with lower transfection efficiency than viral vectors, ${ }^{41}$ but are safer, ${ }^{37}$ protect the cargo from the immune system and can manage 


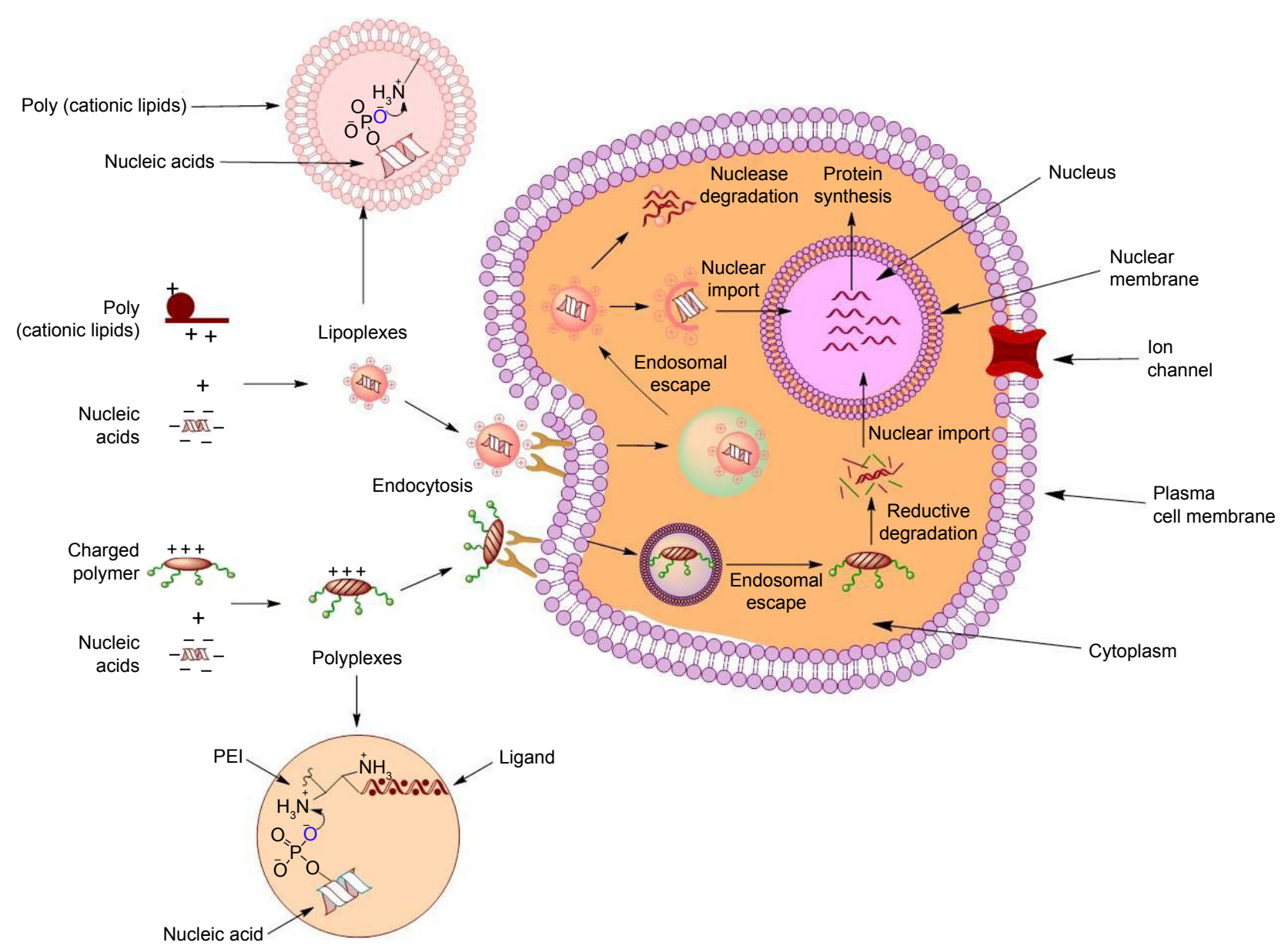

Figure 4 Nonviral gene delivery using lipoplexes and polyplexes. Nucleic acid is complexed with these two types of nonviral delivery systems, and it is internalized through receptor-mediated endocytosis. A large amount of complexes are degraded after their internalization in the endosomal compartments. Only a small fraction enters the nucleus and elicits desired gene expression.

Abbreviation: PEl, polyethylenimine.

larger DNA fragments. ${ }^{40}$ In cancer therapy, it is important to use efficient vectors that can surpass different natural barriers such as extracellular and intracellular membranes, and deliver the genetic material to its target site. ${ }^{41}$ In addition, the side effects such as toxicity, mutagenesis and immunogenicity must be avoided by using materials that are biodegradable and compatible with the systems.

\section{Gold nanoparticles}

Gold nanoparticles are the key focus of biomedical research due to their physical-chemical properties such as shape, surface area, amphiphilicity, carrier capabilities and biocompatibility. However, because of various drawbacks such as low encapsulation efficiency, poor storage stability and slow endosomal escape, the use of these nanoparticles is limited. ${ }^{42}$ Gold nanoparticles can be conjugated with small strands of RNA such as miRNA and siRNA, or a wide range of small molecules or monoclonal antibodies through physical and chemical bonds, leading to various sizes. By loading nanoparticles with RNA, the genetic sequence becomes a target for the cancer cell. siRNA and miRNA perform gene silencing, with siRNA inhibiting the translation of mRNA and miRNA cleaving the mRNA. ${ }^{43}$ Nanoparticles are conjugated with monoclonal antibodies to target a variety of mechanisms, from the simple blocking of the antigen receptor in the effector cells, to cytotoxic action of the cells that express the corresponding antigen. Therapeutic applications include the development of targeted drug delivery systems, hyperthermia, regenerative medicine or radiotherapy. These nanostructures gain attention in various medical fields due to their advantages. Moreover, gold nanoparticles exhibit a low cytotoxicity to the normal cells, ${ }^{44}$ increase the lifespan of the cargo in the bloodstream, ${ }^{43}$ enable easy size control, improve surface chemistry, ${ }^{45}$ increase therapeutic effects, increase accumulation of drug into the cancer cells and improve pharmacokinetic effects and biodistribution. ${ }^{46,47}$ 


\section{Liposomes}

Liposomes were the first colloidal drug carriers ${ }^{48}$ used in gene therapy ${ }^{49}$ and are used for targeted delivery of natural or synthetic chemotherapeutics. They consist of a phospholipid bilayer surface enclosing an aqueous core. ${ }^{8,50,51}$ Liposomes are closed spherical vesicles ${ }^{52}$ and can encapsulate both hydrophilic and hydrophobic drugs ${ }^{53}$ which can be released through diffusion or cell internalization. Liposomes have a structure of hydrophilic heads stabilized by surfactants, and multiple hydrophobic tails (Figure 5). ${ }^{8}$ Due to this structure, aqueous hydrophilic components can be entrapped in the interior, while the lipophilic components can be incorporated between the lipid bilayers. These carriers are attractive for drug designing due to their biodegradability, biocompatibility, low toxicity, ability to encapsulate multicomponents ${ }^{54}$ and ease of surface manipulation, and have been approved for multiple clinical trials. ${ }^{8}$ However, liposomes have several disadvantages such as low encapsulation efficiency, poor storage stability, easy oxidation of liposomal phospholipids and short release time. ${ }^{54}$

Liposomes are widely used to carry the drug inside the lipid bilayer and transfer the contents to plasma proteins by diffusion..$^{55}$ Liposomes have been clinically used to improve drug delivery to tumor sites and diminish the side effects of chemotherapy or antimicrobial therapies, ${ }^{56}$ as well as to enhance specificity to injurious sites. ${ }^{48}$ The stability of liposomes is influenced by the lipid composition and structure, and this contributes to the optimization of liposomal product design. ${ }^{29}$ The stability of liposomal nanostructures includes multiple aspects, such as colloidal and biological stability. Should colloidal stability lack, liposomes form larger-sized particles, and their efficiency as delivery systems is reduced..$^{48}$

Encapsulation of drugs into liposomes has allowed the delivery of therapeutic agents to the target ${ }^{57}$ and also avoided their uptake by the reticuloendothelial system..$^{58,59}$ Due to specific stimuli present at the tumor site, the liposomes are able to target the tumor cells and release the chemotherapeutic agents, which are encapsulated into the nanoparticles. ${ }^{60}$ Liposomal encapsulation of doxorubicin, a topoisomerase II inhibitor, ${ }^{58}$ changes its pharmacology and pharmacokinetics and leads to enhanced drug delivery into tumor sites ${ }^{61}$ and reduced toxic effects, in comparison to classical treatments. ${ }^{59}$ Liposomes release their load in the tumor vessels, which then diffuse through the vascular sites into the distal tumor areas. ${ }^{62}$ Tissue distribution and pharmacokinetic profile of doxorubicin are altered by the

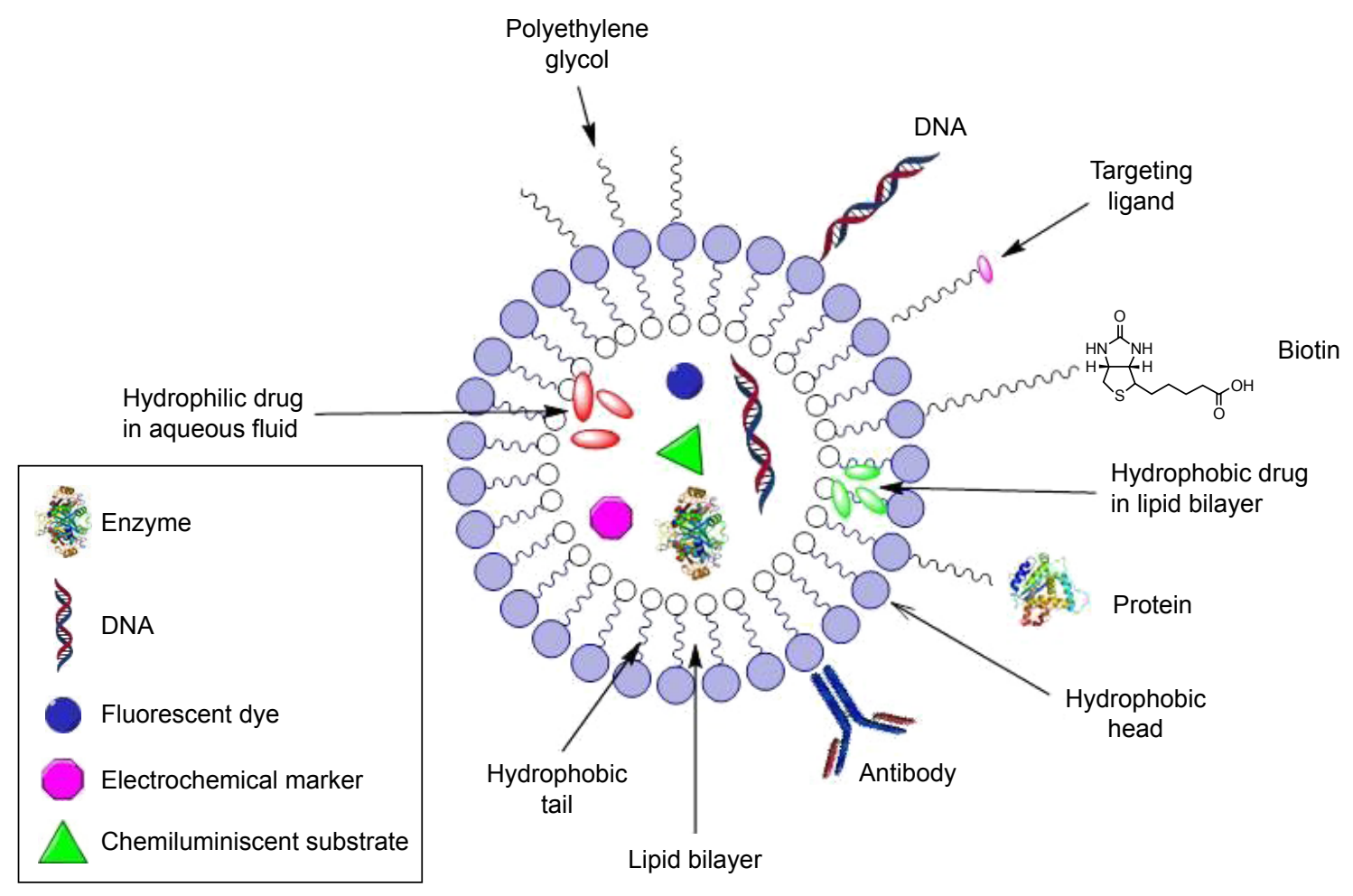

Figure 5 Structure of liposomes. Liposomes are colloidal drug carriers consisting of a phospholipid bilayer surface enclosing an aqueous core. Hydrophilic components can be entrapped inside the aqueous core, while the lipophilic components can be incorporated between the lipid bilayers. On the liposomes surface, different particles that target the interest cells can be attached. To avoid the immune system response, the liposomes surface is loaded with a polymer called polyethylene glycol. Thus, the cargo is protected and is discharged into the target cells. 
PEGylated liposomal doxorubicin, which decreases the rate of left ventricular cardiac dysfunction and symptomatic congestive heart failure. ${ }^{58,63}$

\section{Hybrid systems}

The polymer-lipid hybrid system is a mixture of polymeric nanoparticles and liposomes. The components involved in the hybrid system design present interesting features for potential use in cancer therapy. The core of the hybrid system consists of a biodegradable hydrophobic polymer that allows the encapsulation of water-soluble drugs and thus assures a continuous release. To increase the circulation time in the bloodstream and avoid immune system response, the hybrid system is coated with a hydrophilic shell. Between the hydrophobic core and the hydrophilic shell, the system has a lipid monolayer that prevents diffusion of encapsulated drugs and reduces water penetration inside the nanoparticles. ${ }^{64}$ Chavanpatil et al developed a polymer-surfactant hybrid system for encapsulation of water-soluble drugs and enhancing their release, consisting of polymer (sodium alginate) and dioctylsodium sulfosuccinate (Aerosol OT [AOT], which is an anionic surfactant) forming AOT-alginate nanoparticles. ${ }^{65}$ Bellocq et al developed a polymer-cyclodextrin hybrid system for siRNA delivery. This system was made by condensation of a polycation cyclodextrin with nucleic acid and coating with polyethylene glycol (PEG) to enhance the stability in biological fluids. ${ }^{66}$ Wong et al presented a polymer-lipid hybrid nanoparticle containing cationic doxorubicin, anionic soybean oil-based polymer and stearic acid for water dispensing of the nanoparticle. ${ }^{67}$

Hybrid systems designed from noble metals are promising anticancer agents used in diagnostics and anticancer therapy. Shmarakov et al have tested bimetallic silver-gold ( $\mathrm{Ag}-\mathrm{Au}$ ) nanoparticles on lung cancer cells and observed that $\mathrm{Ag}-\mathrm{Au}$ NPs may serve as a suitable prototype to develop anticancer agents and drug vehicles. ${ }^{68}$ Fakhri et al used in their experiments silver-gold ( $\mathrm{Ag}-\mathrm{Au})$ bimetallic nanoparticles and demonstrated that they have antiproliferative effects on the human lung cancer cell line A549 and the human breast cancer cell line MCF-7. ${ }^{69}$ Mittal et al synthesized silverselenium (Ag-Se) bimetallic nanoparticles functionalized with quercetin and gallic acid and showed their potential antitumor activity against Dalton's lymphoma cells. ${ }^{70} \mathrm{Wu}$ et al showed that silver-gold bimetallic nanostructures present significant cytotoxic effects against the breast cancer cell line MCF-7. ${ }^{71}$ Another study presented the effects of goldplatinum $(\mathrm{Au}-\mathrm{Pt})$ bimetallic nanoparticles on cervical cancer, and Alshatwi et al studied the potential cytotoxic effects of bimetallic nanoparticles. ${ }^{72}$

\section{Dendrimers}

Dendrimers are well-organized nanoscopic macromolecules and have an essential role in the emerging field of nanomedicine. Due to their high water solubility, biocompatibility, polyvalence and precise molecular weight, dendrimers are gaining considerable attention in modern biomedicine. These characteristics make them ideal carriers for drug delivery and targeting applications. They have the ability to interact with cell membranes, cell organelles and proteins. In addition, dendrimers with cationic surface tend to interact with the lipid bilayer, facilitating increased permeability and decreased integrity of biological membranes. Interaction between dendrimers and cell membrane determines the mechanism that causes the leakage of cytosol proteins. ${ }^{73}$ Cell toxicity is determined by the number of end groups and surface charges. It was shown that cationic dendrimers such as polyamidoamine, polypropylenimine and poly-L-lysine expose toxicity in a dose-dependent manner. To prevent the toxicity of dendrimers, the surface groups of cationic dendrimers are modified with neutral molecules. The positive charge of end groups may interact with the negative charge of the membrane, which increases the permeability and facilitates the intracellular delivery of agents. In the case of cationic dendrimers with high charge density, the interaction with the membrane may result in the disruption of membrane integrity and the leakage of important intracellular components which finally causes cell death and toxicity. ${ }^{74}$ Through physical and chemical bonds, dendrimers interact with different classes of drugs, and they can be used for the incorporation of hydrophobic/hydrophilic molecules inside their empty cavities through nonbonding interactions. Another alternative is to attach the drug molecule to its periphery, thus obtaining a complex. The complex is formed due to the electrostatic interactions or conjugation between the drug and the dendrimers. Moreover, the covalent conjugation of drugs to dendrimers may include PEG, p-amino benzoic acid, p-amino hippuric acid and lauryl chains or biodegradable linkages including amide or ester bonds. These conjugates have been found to increase the stability of drugs and blood resistance time, and cause enhanced therapeutic action. ${ }^{73}$

\section{Carbon nanotubes}

CNTs have cylindrical shape and belong to the fullerene family of carbon allotropes, ${ }^{75}$ consisting of a hexagonal arrangement of sp2-hybridized carbon atoms. The wall of CNTs is formed from single or multiple layers of graphene sheets. When a single sheet is rolled up, it forms single-walled carbon nanotubes, and multiwalled carbon nanotubes are 
obtained by rolling up more than one sheet. ${ }^{76} \mathrm{CNT}$ display abilities for drug loading on the surface or in the inner core through covalent and non-covalent interactions. These nanoparticles are able to immobilize therapeutic agents such as drugs, proteins, DNA and antibodies on the outer wall, or encapsulate them inside the nanotubes, decreasing the cytotoxicity for healthy tissues. Due to their nanoneedle-like structure, carbon nanoparticles are efficiently taken up and translocated into the cytoplasm of target cells without causing cell death. Their applications are limited due to the fact that CNTs are hydrophobic in nature and insoluble in water, and are accumulated in internal organs, having a low degradation rate. ${ }^{77}$ To eliminate the undesirable effects and to facilitate their use in medical applications, various methods of functionalization of CNTs, such as adsorption and electrostatic and covalent interaction, are used. To increase the systemic retention, circulation time and the solubility of CNTs, a hydrophilic biocompatible polymer with neutral charge such as PEG or polyethylene oxide is used. ${ }^{78,79}$

\section{Functionalization and applications of nanoparticles in chemotherapeutic delivery}

In this section, we summarize some examples of nanomaterials used for nanoparticle functionalization. We also describe some chemotherapeutic agents used in cancer therapy and their applications. Nanoparticles can be functionalized with amine, carboxylic acid, p-nitrophenyl carbonyl, thiol, maleimide, aldehyde or any ligand that can be attached to the surface, ${ }^{98}$ small molecule, dendrimers, biomolecules and polymers. ${ }^{99}$ In addition, they can be labeled with different types of radioisotopes such as fluorine-18, copper-64, arsenic-72, germanium-69 and zirconium-89. Design and synthesis of radiolabeled nanoparticles is a technique that is faster, easier, more stable and more specific for the next generation of nano-oncology. ${ }^{100}$ Liposome changes are performed when needed to attach large targeting molecules, such as proteins, but due to conformational changes, this may cause a decrease in their targeting efficiency. If the target molecule is attached too close to the liposomal bilayer, the stability of the liposome may be altered. To avoid these disadvantages, longer PEG moieties are used, which contain functional groups, and due to steric reasons, may influence the targeting efficiency. Nanoparticles encapsulate the chemotherapeutic agent and are functionalized with specific ligands that are directed to the specific molecule found on the cancer cell. These particular surface markers are used for the development of novel target ligands. ${ }^{101}$ The above-mentioned markers need to be overexpressed on the surface of cancer cells, leading to the selective delivery of the cytotoxic drugs only to these cells. ${ }^{102}$ These targeted deliveries reduce the toxic effect of the chemotherapeutic agents on healthy cells, and allow the delivery of higher doses of agents to cancer cells. To avoid the interaction with the innate immune cells, nanoparticles are coated with a bio-polymer, such as PEG, that keeps them from being recognized and cleared by the mononuclear phagocyte system. ${ }^{6}$ PEG functionalization is used in a wide range of nanomedical applications due to its flexible structure, non-reactivity, low toxicity ${ }^{103,104}$ and solubility in water ${ }^{104-107}$ and polar and nonpolar solvents ${ }^{51,105}$ such as tetrahydrofuran, chloroform, dimethylsulfoxide ${ }^{105}$ or methanol. ${ }^{105,106} \mathrm{PEG}$ is a hydrophilic polymer ${ }^{106-111}$ with terminal hydroxyl groups ${ }^{106}$ that covalently attach to the nanoparticles' surface and form a protective shell, which inhibits the binding of serum proteins to the liposome, ${ }^{112}$ increasing liposome circulation time,${ }^{49,109}$ preventing particle aggregation and protecting the liposomes from opsonization and the mononuclear phagocyte system. ${ }^{48}$

A wide range of ligands can be incorporated on the surface of nanoparticles, allowing them to be used for detecting biomolecules or cells, diagnosis of diseases and intracellular delivery. Nanoparticles functionalized with ligands show different affinity to proteins and cell surface molecules. Nanoparticles functionalized with positively charged ligands present higher internalization into cells when compared to neutral and negatively charged ones. ${ }^{99}$ Positively charged magnetic iron oxide $\left(\mathrm{Fe}_{2} \mathrm{O}_{4}\right)$ nanoparticles coated with dendritic guanidine head groups were found to be efficient in HIV-1 trans-activator detection. ${ }^{113}$ Amine-functionalized mesoporous silica nanoparticles are used as gene delivery systems for both in vitro and in vivo studies. ${ }^{114}$ Nanoparticles functionalized with oligonucleotides have offered new opportunities in molecular diagnostics, such as the detection of nucleic acids. ${ }^{115}$ For example, oligonucleotide-Au nanoparticles hybridized with fluorophore-labeled complementary sequences are used to visualize and quantify mRNA in living cells. ${ }^{116}$ Nanoparticles can also be coated with proteins and antibodies that bind to the surface receptors, providing targeted delivery. Nanoparticles coated with Herceptin, a small molecule that targets the Her-2 receptor, assure a useful tool for targeting particles for imaging and photothermal therapy. Magnetic nanoparticles coated with specific proteins can be used as imaging agents, because they can bind to specific tumor tissues. ${ }^{117}$

Pharmacokinetic and pharmacodynamic profiles of nanoparticle therapeutic agents are dependent on physical 
aspects such as size, shape, surface charge and PEGylation (Table 2).

Gold nanoparticles are conjugated with different types of agents such as drugs, monoclonal antibodies, aptamers, peptides, RNA transcripts (siRNA and miRNA), fluorophores, PEG and 1,4,7,10-tetraazacyclododecane-1,4,7,10tetraacetic acid for chelating ${ }^{64} \mathrm{Cu}$, or small natural or synthetic molecules. ${ }^{134}$ Dendrimers can be functionalized with various targeting moieties such as folic acid, peptides, monoclonal antibodies and sugar groups. ${ }^{73}$ Anthracyclines (ANTs) are cancer drugs effectively used for treating malignant neoplasms. ${ }^{135}$ Doxorubicin, an amphiphilic drug with small molecular weight, ${ }^{136,137}$ is an effective ANT antibiotic $^{27,138}$ used for the treatment of multiple types of cancers. Doxorubicin's advantages include high response rate, increased time to disease progression and low therapeutic index. It is not recommended for patients with high risks of developing cardiac toxicity ${ }^{139-142}$ with adjacent congestive heart failure, arrhythmias or conductivity dysfunction. ${ }^{137}$ The high rates of adverse drug reactions limit the use of this drug. The adverse effects are dose-dependent and are characterized by injuries in the liver, brain, kidney ${ }^{143}$ and gastrointestinal tract. ${ }^{144}$ Enhancing strategies for protection from these severe side effects ${ }^{145}$ by reducing the cumulative dose of cardiotoxic agents, ${ }^{146}$ while increasing the cytotoxic effects on malignant cells, ${ }^{145}$ has become a high priority. Drugs affect DNA intercalation and helicase inhibition causing a cytotoxic mechanism, ${ }^{138}$ DNA cross-linking and free-radical formation. ${ }^{147}$ Tumor growth is inhibited by triggering cell apoptosis or inhibition of angiogenesis. ${ }^{148}$ Doxorubicin interacts with dsDNA and nucleic acids, causing single- and double-strand breaks, but at the same time, it increases cell membrane permeability and inactivates membrane receptors. ${ }^{135}$ Damage induced by free radicals affects the heart through high oxidative metabolism and low level of antioxidant defenses, and regarding the liver, free radicals induce cell death and tissue damage. ${ }^{143}$ Through active internalization, doxorubicin exhibits accelerated intracellular trafficking in vivo. Greater accumulation of doxorubicin relies on internalization of carriers, which triggers a mechanism for fast release of drugs in cancer cells.

The delivery of chemotherapeutics into cancer cells is based on liposomal penetration into the tumor interstitia and release of therapeutic agents. Poor penetration leads to low antitumor efficacy. Through nanoparticles and targeting ligands with low affinity, intratumor distributions can be improved. Intracellular trafficking of the released agent is affected by the $\mathrm{pH}$ values and size of the agent. For doxorubicin, a weak base that limits the permeability of the cell membranes leads to decreased endosomal $\mathrm{pH}$ values and allows diffusion through the endosomal membrane to the cytoplasm. ${ }^{149}$ Another problem during therapy is the development of resistance to treatment. Doxorubicin is a substrate for various ATP-binding cassette membrane pumps, such

Table 2 Nanoparticle functionalization and physicochemical characteristics

\begin{tabular}{|c|c|c|}
\hline $\begin{array}{l}\text { Nanoparticle } \\
\text { characteristics }\end{array}$ & Advantages & Disadvantages \\
\hline PEGylation & $\begin{array}{l}\text { Increased circulation time protecting from opsonization, } \\
\text { improved biocompatibility and low immunogenicity }\end{array}$ & $\begin{array}{l}\text { Blood clearance is accelerated due to production of PEG-specific } \\
\text { antibody: "PEG dilemma" } 98,100,118-121\end{array}$ \\
\hline Size & $\begin{array}{l}\text { The optimal size of nanoparticles is between } 30 \text { and } \\
50 \mathrm{~nm} \text {, which improves accumulation in tumor }\end{array}$ & $\begin{array}{l}\text { Nanoparticles of }<10-\mathrm{nm} \text { diameter are rapidly dispersed in lymph } \\
\text { nodes and eliminated by fast renal clearance } \\
\text { Nanoparticles of }>100-\mathrm{nm} \text { diameter are accumulated at the injection } \\
\text { site or trapped by the spleen, lung and liver macrophages }{ }^{120,122-125}\end{array}$ \\
\hline Surface charge & $\begin{array}{l}\text { The optimal surface charge of nanoparticles is neutral; } \\
\text { negative-charged nanoparticles have extended } \\
\text { bloodstream lifetime and improved tumor uptake }\end{array}$ & $\begin{array}{l}\text { Positive charge facilitates the binding of nanoparticles to the cell } \\
\text { membrane and might strengthen the nonspecific binding of vectors } \\
\text { to normal tissue, and promote platelet aggregation and hemolysis } \\
\text { If the zeta potential is between }-25 \text { and }+25 \mathrm{mV} \text {, the nanoparticles } \\
\text { are considered unstable after long-term storage }\end{array}$ \\
\hline Shape & $\begin{array}{l}\text { Shapes of particles minimize phagocytosis, leading to } \\
\text { longer blood lifetimes and improve the ability of drug } \\
\text { delivery systems to reach tumor tissues }\end{array}$ & $\begin{array}{l}\text { Extravasation ability is dependent on morphological characteristics of } \\
\text { the tumor }{ }^{\mid 20,125,130,131}\end{array}$ \\
\hline $\begin{array}{l}\text { Stimulus- } \\
\text { responsive } \\
\text { delivery systems }\end{array}$ & $\begin{array}{l}\text { Using magnetic field, the characteristics can be improved } \\
\text { to promote the accumulation of nanoparticles carrying } \\
\text { the therapeutic agents in tumors or thermosensitive } \\
\text { polymeric delivery systems and local hyperthermia }\end{array}$ & $\begin{array}{l}\text { Sensitive to tumor environment and have the feasibility of triggering } \\
\text { systems }{ }^{120,132,133}\end{array}$ \\
\hline $\begin{array}{l}\text { Modification with } \\
\text { a target moiety }\end{array}$ & $\begin{array}{l}\text { Cause strong binding and internalization of nanoparticles } \\
\text { into cancer cells more efficiently }\end{array}$ & $\begin{array}{l}\text { Targeted nanoparticles can lose their specificity due to shielding with } \\
\text { protein corona, and have low tumor uptake }\end{array}$ \\
\hline
\end{tabular}

Abbreviation: PEG, polyethylene glycol. 
as P-glycoprotein and multidrug resistance-related proteins. As a result of the overexpression of these transporters, doxorubicin can be removed from cancer cells, reducing its intracellular accumulation. ${ }^{150}$

Doxorubicinol, a doxorubicin metabolite, is cytotoxic, being responsible for the adverse effects. To alleviate acute toxicities ${ }^{151}$ and improve antitumor effect, the chemotherapeutic agent is encapsulated into a PEGylated liposome. This clinical product, Doxil (liposomal doxorubicin), is an anticancer drug ${ }^{28}$ that shows increased microvascular permeability of the tumor with a prolonged duration of circulation in plasma and decreased distribution volume, ${ }^{152}$ increasing tumor uptake through EPR effect. ${ }^{137,151}$ To avoid drug interaction with plasma proteins such as opsonins, high-density lipoproteins and low-density lipoproteins, or elimination by macrophages, liposomes' surface is conjugated with PEG. The external part of Doxil is formed from a lipid bilayer coated with PEG, and the molecules of doxorubicin are encapsulated into the aqueous core ${ }^{137,153}$ with better pharmacokinetic profile. ${ }^{109}$ Doxil is the first nanodrug approved by the US Food and Drug Administration, and is extensively used in the clinic for cancer patients. ${ }^{28}$ Through lipid bilayer stabilization and steric hindrance, the interaction with the plasma proteins is decreased, and the recognition by the macrophages is diminished. ${ }^{13}$ Doxil is used to treat AIDSrelated Kaposi's sarcoma, metastatic breast cancer and ovarian cancer, ${ }^{11,136,151}$ with a better toxicity profile and reduced incidence of cardiactoxicity. ${ }^{154,155}$ At high dose or short dosing intervals, some forms of toxicity, including acute infusion reaction, mucositis, palmar-plantar erythrodysesthesia, ${ }^{139}$ nausea or vomiting, are present. ${ }^{153}$ Doxorubicin is deposited in the liver, spleen and tumor. ${ }^{154,155}$ An attractive strategy to increase tumor growth via modulating different signaling pathways is to combine multiple drugs with different mechanisms of actions. ${ }^{148}$

\section{miRNA and siRNA delivery systems for applications in cancer therapy}

In the last decades, alternative delivery systems functionalized with RNA (miRNA and siRNA) have gained increasing attention. Here, we summarize the mechanism of action and the benefits of such delivery systems in cancer therapy. At the moment, these delivery systems are intensively studied in in vitro/in vivo experiments and also in clinical trials.

miRNAs are short molecules of noncoding RNAs consisting of 20-24 nucleotides that exhibit important roles in all biological pathways in multicellular organisms, including mammals, ${ }^{156-158}$ and are responsible for the regulation of posttranscriptional gene expression. ${ }^{45,159}$ miRNAs are necessary for normal cellular processes, being deregulated in almost all the diseases, including cancer. ${ }^{42,158}$ Mature miRNAs are processed from hairpin structures into pre-miRNA precursors (60-100 nucleotides). Mature miRNAs are obtained after RNase III Dicer recognition and cleavage into small dsRNA duplexes. ${ }^{160}$ miRNAs are involved in many processes, such as development, cell proliferation, apoptosis, tumorigenesis, ${ }^{45}$ cell cycle control, differentiation, migration and metabolism. ${ }^{156}$ miRNAs can act similar to oncogenes or tumor suppressor genes. ${ }^{45,160-164}$

In mammals, miRNAs binding to the $3^{\prime}$-untranslated region halts translation and results in mRNA degradation. ${ }^{159}$ Dysregulation of miRNAs causes gene expression imbalance that is related to the dysregulation of key cellular pathways. ${ }^{165}$ In recent published papers, different types of miRNAs were used in the medical field as therapeutic agents loaded on the surface of nanoparticles (Table 3).

A great applicability of miRNAs is provided by the use of artificial structures able to restore the normal expression level of a gene, called miRNA mimics and anti-miRNAs (anti-miRs). ${ }^{164}$ miRNA mimics are RNA duplexes that are identical to the mature miRNA sequence. An miRNA mimic is designed to have the function of the endogenous miRNA, attempting to restore its loss of function as a tumor suppressor. Anti-miRs are synthetic-modified oligonucleotides that help to explain the function of miRNAs and their targets. ${ }^{164,183}$ They are complementary to the mature miRNAs or their precursors, designed to block their function in RNAinduced silencing complex (Figure 6). ${ }^{184}$

siRNAs are short RNA duplexes that gained attention due to their role in gene regulation, making them targets for drug discovery and development. siRNAs act by their ability to specifically inhibit a target gene. ${ }^{185}$ Delivery systems are designed to protect the cargo from premature nuclease degradation. ${ }^{185}$ miRNA and siRNA have an intracellular site of action, but due to their intrinsic properties such as hydrophilic nature, high molecular weight and negative charge, the permeability for the cellular membrane is decreased. Both types of RNA molecules are used for many disorders, and due to their similar physicochemical properties and intracellular site of action, similar delivery technologies can be used for both transcripts. ${ }^{186}$ Therapeutic applications of siRNAs rely on their local delivery to the specific tissue or tumor site. In cancer therapy, the systemic delivery of siRNA has become a major topic and faces many challenges such as interaction with specific gene targets, obtaining pharmacologically effective levels, stability in circulation, improved cellular uptake, monitoring the distribution and therapeutic efficacies. Due to these challenges, novel delivery 
Table 3 Relevant examples of miRNAs loaded on nanoparticle surfaces used for medical applications

\begin{tabular}{|c|c|c|c|}
\hline Delivery system & miRNA & miRNA type & Cancer \\
\hline \multicolumn{4}{|l|}{ Lipid vesicle } \\
\hline Cationic lipoplex & miR-29b, miR-II3b & Mimic & Lung $^{166,167}$ \\
\hline \multirow[t]{2}{*}{ Lipid-based nanoparticles } & miR-34a, miR-I43 & Mimic & Pancreas ${ }^{168}$ \\
\hline & cluster, miR-145 cluster & & \\
\hline Liposomes coated with $\alpha v \beta 3$-targeted nanoparticles & miR-I32 & Anti-miR & Breast ${ }^{169}$ \\
\hline \multirow[t]{2}{*}{ Neutral lipid } & miR-34a & Mimic & Lymphoma and prostate \\
\hline & miR-34a, let7 & & Lung ${ }^{170-173}$ \\
\hline Lactosylate gramicidin-coated lipid nanoparticles & miR-I55 & Anti-miR & Hepatocellular carcinoma ${ }^{174}$ \\
\hline \multirow[t]{2}{*}{ Liposome-polycation-hyaluronic acid } & $\operatorname{miR}-34 a$ & Mimic & Melanoma \\
\hline & miR-296 & Anti-miR & Angiogenesis ${ }^{175,176}$ \\
\hline \multicolumn{4}{|l|}{ Cationic polymers } \\
\hline PU-PEI & miR-I45 & Mimic & Lung 177 \\
\hline CD-PEI coated with RGD-targeting peptide & miR-34a & Mimic & Lung $^{178}$ \\
\hline \multicolumn{4}{|l|}{ Dendrimers } \\
\hline PAMAM nanoparticles coated with 5-FU & miR-2I & Anti-miR & Glioma ${ }^{179}$ \\
\hline \multirow[t]{2}{*}{ Gold nanoparticles } & miR-3I & Mimic & Neuroblastoma \\
\hline & miR-I 323 & Anti-miR & Ovarian $^{42}$ \\
\hline \multicolumn{4}{|l|}{ Encapsulation } \\
\hline PLGA nanoparticles & miR-I55 & Anti-miR & Lymphoma $^{180}$ \\
\hline \multicolumn{4}{|l|}{ Silica nanoparticles } \\
\hline Coated with cell surface antigen GD2 & $\operatorname{miR}-34 a$ & Mimic & Neuroblastoma $^{181}$ \\
\hline \multicolumn{4}{|l|}{ Gold nanoparticles } \\
\hline- & $\operatorname{miR}-29$ & Anti-miR & HeLa cells ${ }^{165}$ \\
\hline \multicolumn{4}{|l|}{ Magnetic nanoparticles } \\
\hline $\begin{array}{l}\text { Conjugated with fluorescence and ASI4aa } \\
\text { aptamer-targeting nucleolin }\end{array}$ & miR-22I & Anti-miR & Astrocytoma ${ }^{182}$ \\
\hline
\end{tabular}

Abbreviations: miRNAs, microRNAs; anti-miR, anti-miRNA; PU-PEl, polyurethane-polyethylenimine; CD-PEI, cyclodextrin-polyethylenimine; PAMAM, polyamidoamine; 5-FU, 5-fluorouracil; PLGA, poly-lactic-co-glycolic acid; RGD, arginine-glycine-aspartic; GD2, ganglioside antigen.

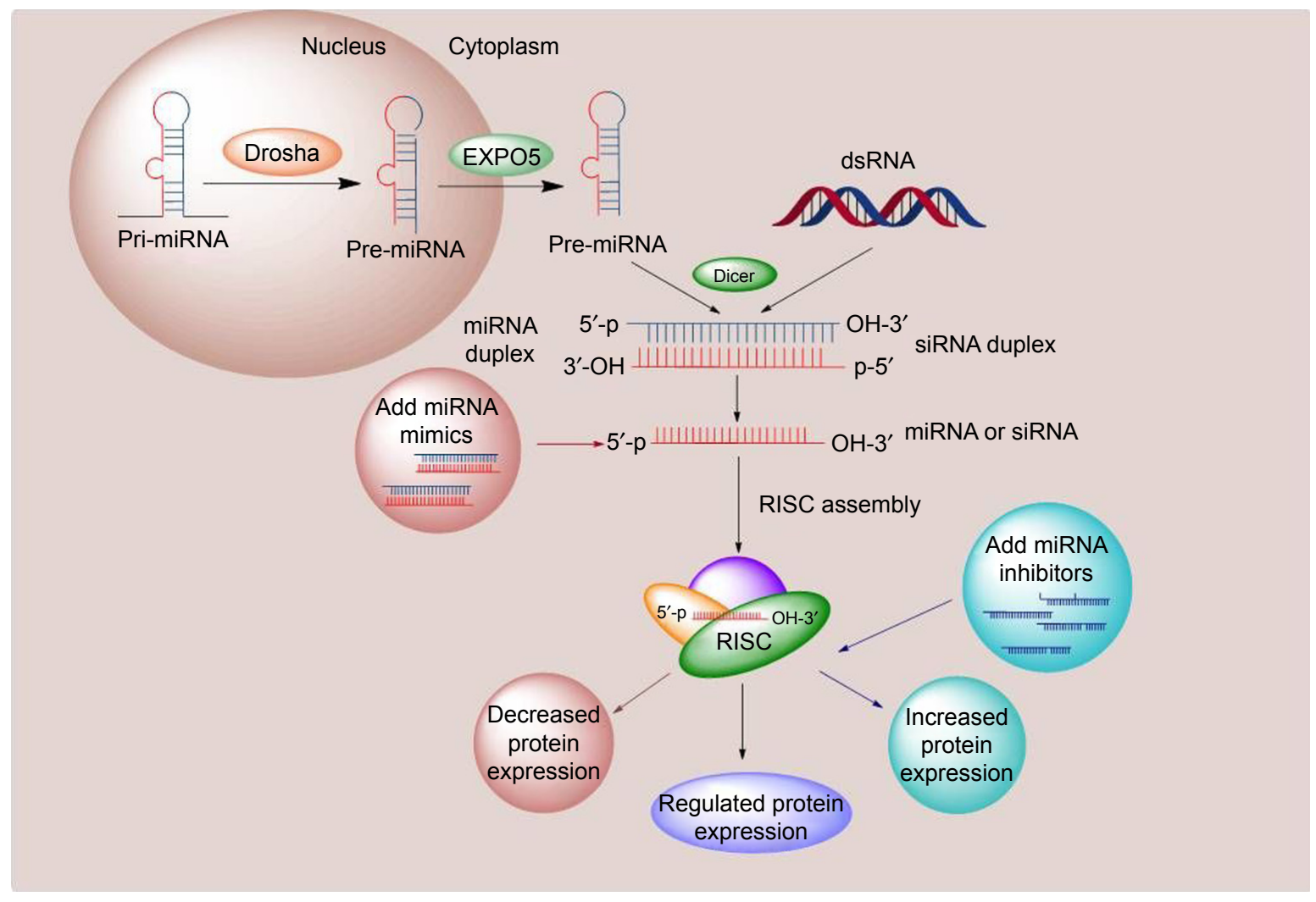

Figure 6 miRNA and siRNA mechanism. miRNA is first transcribed in the nucleus as primary miRNA and then is activated by the RNase III Drosha to create precursor miRNA. The siRNA mechanism starts from dsRNA being transferred into cytoplasm. miRNA mimic involves the reintroduction of a tumor suppressor miRNA to restore a loss of function. Anti-miRNA traps the endogenous miRNA in a configuration that is unable to be processed by RISC.

Abbreviations: miRNA, microRNA; siRNA, small interfering RNA; dsRNA, double-stranded RNA; RISC, RNA-induced silencing complex; pri-miRNA, primary microRNA; pre-miRNA, precursor microRNA; expo5, exportin-5. 
Table 4 Different types of delivery systems used for siRNA delivery

\begin{tabular}{|c|c|c|c|}
\hline $\begin{array}{l}\text { siRNA-based } \\
\text { delivery systems }\end{array}$ & Type of delivery systems & Advantages & Disadvantages \\
\hline Liposome & $\begin{array}{l}\text { DOTAP cationic liposomes, PEGylated } \\
\text { DOTAP cationic liposomes, PIL, RGD- } \\
\text { modified DOTAP cationic liposomes }\end{array}$ & $\begin{array}{l}\text { High transfection efficiency, } \\
\text { pharmacokinetic properties are improved; } \\
\text { toxicity and immunogenicity are decreased; } \\
\text { protection from the enzymatic degradation } \\
\text { and renal release is reduced; conjugated } \\
\text { with different types of specific ligands }\end{array}$ & $\begin{array}{l}\text { Cationic lipid caused cell toxicity; } \\
\text { not always validated on in vivo } \\
\text { tests }^{185}\end{array}$ \\
\hline Nanoparticle & $\begin{array}{l}\text { PEGylated nanoparticles; calcium phosphate } \\
\text { nanoparticles; chitosan nanoparticles; PEI } \\
\text { nanoparticles; MR-sensitive liposome- } \\
\text { entrapped siRNA nanoparticles }\end{array}$ & $\begin{array}{l}\text { Increased circulation time; } \\
\text { pharmacokinetics, pharmacodynamics, } \\
\text { biodistribution and toxicology are } \\
\text { improved }\end{array}$ & $\begin{array}{l}\text { Reticuloendothelial system } \\
\text { recognized nanoparticles bigger than } \\
100 \mathrm{~nm} \text { and having a short half-life }{ }^{187}\end{array}$ \\
\hline Dendrimer & $\begin{array}{l}\text { PPI, PAMAM, dendrosomes, PAMAM- } \\
\text { PEG-PLL }\end{array}$ & $\begin{array}{l}\text { Internal cavities encapsulate siRNA; having } \\
\text { accessible terminal functional groups that } \\
\text { conjugate ligands; circulation half-life is } \\
\text { improved due to the higher-branched } \\
\text { dendrimers; molecular weight is controlled }\end{array}$ & $\begin{array}{l}\text { Increased cytotoxicity; limited for } \\
\text { clinical use }^{186}\end{array}$ \\
\hline Carbon nanotube & SWNT and MWNT & $\begin{array}{l}\text { Controlled and targeted RNA delivery; } \\
\text { having the ability to penetrate the cells due } \\
\text { to the needle mechanism }\end{array}$ & $\begin{array}{l}\text { Accumulation in internal organs, low } \\
\text { degradability and excretion rate }\end{array}$ \\
\hline
\end{tabular}

Abbreviations: siRNA, small interfering RNA; DOTAP, N-[I-(2,3-dioleoyloxy)propyl]-N,N,N-trimethylammonium; PIL, PEGylated immunoliposome; PEI, polyethylenimine; MR, magnetic resonance; PPI, polypropylenimine; PAMAM, polyamidoamine; PEG, polyethylene glycol; PLL, poly-L-lysine; SWNT, single-walled carbon nanotube; MWNT, multiwalled carbon nanotube; DOTAP, N-[I-(2,3-dioleoyloxy)propyl]-N,N,N-trimethylammonium methylsulfate; RNA, ribonucleic acid; RGD, arginine-glycine-aspartic.

vehicles such as lipid-, polymer- and nanoparticles were developed for the systemic delivery of siRNAs (Table 4). These delivery systems have been tested on animal models, and some disadvantages regarding toxicity, immune and inflammatory responses gene-control and gene-targeting issues were observed. ${ }^{187}$

siRNA and miRNA present similar physicochemical properties but distinct functions (Table 5). They are short RNA duplexes that produce gene-silencing effects by targeting mRNA(s), but their mechanism of action and requirements for sequence design and therapeutic applications are different. For clinical development, they present some disadvantages, such as poor stability in vivo, delivery challenges and off-target effects. ${ }^{186}$

\section{Nanoscale immunotherapy}

Tumor immunotherapy has been shown to complement available treatment modalities to fight severe cases of relapsed disease, to provide so far unseen clinical results. This novel treatment method is based on the use of in vitro-modified adoptively transferred $\mathrm{T}$ lymphocytes to express an artificial signaling molecule named CAR which would specifically redirect the modified lymphocytes to the surface antigens expressed only by malignant cells. ${ }^{190} \mathrm{CARs}$ typically encode an extracellular antibody-derived domain to bind a surface antigen linked to an intracellular signaling domain that mediates $\mathrm{T}$ cell activation such as TCR $\zeta$ chain, and various co-stimulatory domains such as CD28 or 4-1BB intracellular chains. ${ }^{191}$ In principle, any surface antigen can be targeted

Table 5 Comparison of general properties between miRNA and siRNA

\begin{tabular}{|c|c|c|c|c|c|c|}
\hline $\begin{array}{l}\text { Nucleic } \\
\text { acids }\end{array}$ & Occurrence & Configuration/length & $\begin{array}{l}\text { Complementarity to } \\
\text { target mRNA }\end{array}$ & Action & Function & Clinical uses \\
\hline miRNA & $\begin{array}{l}\text { Plants and } \\
\text { animals }\end{array}$ & Single stranded/19-25 nt & $\begin{array}{l}\text { Not exactly a perfect match, } \\
\text { only at seed level; a single } \\
\text { miRNA may target up to } \\
\text { hundreds of mRNAs }\end{array}$ & $\begin{array}{l}\text { Inhibit translation } \\
\text { of mRNA }\end{array}$ & $\begin{array}{l}\text { Modulators of } \\
\text { gene expression } \\
\text { regulation }\end{array}$ & $\begin{array}{l}\text { Used as drug targets or } \\
\text { biomarkers and diagnostic } \\
\text { tools }^{186,189}\end{array}$ \\
\hline siRNA & $\begin{array}{l}\text { Plants and } \\
\text { lower animals }\end{array}$ & Double stranded/2I-22 nt & $\begin{array}{l}\text { Perfect match, siRNAs knock } \\
\text { down specific genes, with } \\
\text { minor off-target exceptions }\end{array}$ & $\begin{array}{l}\text { Cleavage of } \\
\text { mRNA }\end{array}$ & $\begin{array}{l}\text { Act as gene- } \\
\text { silencing guardians }\end{array}$ & $\begin{array}{l}\text { Used to knock down } \\
\text { specific genes, with } \\
\text { application in clinical trials } \\
\text { as therapeutic agents }{ }^{186,189}\end{array}$ \\
\hline
\end{tabular}

Abbreviations: miRNA, microRNA; siRNA, small interfering RNA; nt, nucleotides. 
with CAR in a non-HLA-restricted manner. A large number of CARs targeting diverse tumors have been recently developed, and there are ongoing multiple clinical trials. One of the most successful examples of CAR-based immunotherapy is the treatment of $\mathrm{B}$ cell acute and chronic leukemia by targeting the cell surface antigen CD19. ${ }^{192}$ However, in spite of these highly encouraging results, major questions remain unresolved. The major problem with CAR-based therapy is the unpredictable treatment responses. A subset of patients encounter limited or missing expansion of infused CAR $\mathrm{T}$ cells that might be caused by inefficient activation of CAR $\mathrm{T}$ cell in combination with immunosuppressive environment within the tumor stroma. In other patients, there is a complete depletion of all B type-lymphocytes also including the nonmalignant ones.

Advanced medicinal products constitute a group of novel treatment modalities and are rapidly being developed by scientific communities worldwide. ${ }^{193}$ Recently, CAR-based cancer immunotherapy was listed as one of the breakthroughs of the year 2016, and this method is tested in many clinical studies in the US and EU for the therapy of many types of cancer. Adoptive T cell therapy is an important approach to cancer treatment that assumes the infusion of tumorspecific T cells. ${ }^{194} \mathrm{~T}$ cells for adoptive therapy of patients with hematological malignancies can originate from an allogeneic donor. Several techniques have been developed to remove alloreactive $\mathrm{T}$ cells from grafts of stem cells to reduce the risk of graft-versus-host disease (GVHD). It has been shown recently that alloreactivity stems mainly from naïve $\mathrm{T}$ cells (CD45RA+) and not from memory $\mathrm{T}$ cells. Depletion of graft cells from naïve $T$ cells could be a new approach for GVHD prophylaxis. Moreover, the depletion procedure sustained the $\mathrm{T}$ cell reactivity to pathogens. The elimination of all CD45RA+ cells also depletes naïve CD4+ Treg cells and CD45RA+ effector memory T cells (TEMRA). TEMRA cells are expanded in subjects chronically infected with $\mathrm{HCMV},{ }^{195}$ and they represent senescent and terminally differentiated (CD27-, CD28-, CD57+) cytotoxic T cells which produce large amounts of granzyme and IFN gamma and have a low proliferative potential, and thus, the presence of such cells in expanded antiviral T cells is disadvantageous. The nanoscale immunotherapy represents a fundamental starting point for all forms of cancer.

\section{Conclusion and perspectives}

Nanotechnology is a field with high applicability in basic and translational medicine. Nanomedicine relies on various nanostructure designs, which are conjugated with a wide range of specific targeting agents used for clinical applications, like early diagnosis or disease treatment. The specific agents are attached to the nanoparticles' surface, which promote the accumulation and delivery of those agents in the neoplastic tissue. Nanomedicine's aim is to replace the chemotherapeutic drugs that are highly invasive or nonspecific with particular targeting agents with potential in detection, diagnosis, imaging, targeted delivery and controlled release of therapeutic cargo. In clinical trials, delivery system-based therapies meet many obstacles such as therapeutic molecules stability, decreased nonspecific inflammation, controlled release of therapeutic molecules, specificity and efficiency of the delivery systems. To enhance the stability of therapeutic molecules and to decrease the nonspecific immunogenicity, chemical modifications are required, while for efficient and specific delivery, tailored carriers are needed. RNA therapeutics exhibit great potential in clinical trials, while needing advanced delivery strategies to perform and play their roles in cancer therapy. There are some important component designs, such as PEGylated, tumor-specific ligand that coats the nanoparticles in combination with other light-, thermal-, $\mathrm{pH}$ - or magnetic-sensitive components, that enhance the precision, specificity and efficiency of therapeutic molecules to act on tumor sites and tumor cells. Also, a great potential is offered by biochemical modifications that increase the potency and decrease the off-target effects and other side effects of therapeutic drugs, allowing the implementation of new personalized drugs in clinical use.

\section{Acknowledgments}

This work was supported by a POC grant, entitled "Clinical and economical impact of personalized targeted anti-microRNA therapies in reconverting lung cancer chemoresistance"CANTEMIR. Prof Berindan-Neagoe received funding from an international collaboration grant with South Africa, contract $7 \mathrm{BM} / 2016$. Ancuta Jurj has received an internal grant of the "Iuliu Haţieganu" University of Medicine and Pharmacy (UMF), Cluj-Napoca, for sustaining PhD Research Project (Application of nanotechnologies in malignant tumours), grant number 5200/52/15.04.2016. Ciprian Tomuleasa received funding from the Romanian Research Ministry, contracts PN-II-RU-TE-2014-4-1783 (awarded to Young Research Teams) and CNFIS-FDI-2017-1350 (awarded to Institutional Development Funds), as well as from an international collaboration grant between Romania and People's Republic of China, contract 57 BM/2016. 


\section{Disclosure}

The authors report no conflicts of interest in this work.

\section{References}

1. Rosenzweig SA. Acquired resistance to drugs targeting receptor tyrosine kinases. Biochem Pharmacol. 2012;83(8):1041-1048.

2. Gultekin M, Dursun P, Vranes B, et al. Gynecologic oncology training systems in Europe: a report from the European network of young gynaecological oncologists. Int J Gynecol Cancer. 2011;21(8): $1500-1506$.

3. Braicu C, Chiorean R, Irimie A, et al. Novel insight into triple-negative breast cancers, the emerging role of angiogenesis, and antiangiogenic therapy. Expert Rev Mol Med. 2016;18:e18.

4. Vlad C, Kubelac P, Vlad D, Irimie A, Achimas Cadariu P. Evaluation of clinical, morphopathological and therapeutic prognostic factors in rectal cancer. Experience of a tertiary oncology center. J BUON. 2015; 20(1):92-99.

5. Herbrink M, Nuijen B, Schellens JH, Beijnen JH. Variability in bioavailability of small molecular tyrosine kinase inhibitors. Cancer Treat Rev. 2015;41(5):412-422.

6. Banu H, Sethi DK, Edgar A, et al. Doxorubicin loaded polymeric gold nanoparticles targeted to human folate receptor upon laser photothermal therapy potentiates chemotherapy in breast cancer cell lines. J Photochem Photobiol B. 2015;149:116-128.

7. Fujita Y, Kuwano K, Ochiya T. Development of small RNA delivery systems for lung cancer therapy. Int J Mol Sci. 2015;16(3):5254-5270.

8. Kleinstreuer C, Childress E, Kennedy A. Chapter 10 - Targeted drug delivery: multifunctional nanoparticles and direct micro-drug delivery to tumors. In: Becker SM, Kuznetsov AV, editors. Transport in Biological Media. Boston: Elsevier; 2013:391-416.

9. Wilczewska AZ, Niemirowicz K, Markiewicz KH, Car H. Nanoparticles as drug delivery systems. Pharmacol Rep. 2012;64(5):1020-1037.

10. Shahin M, Soudy R, El-Sikhry H, Seubert JM, Kaur K, Lavasanifar A. Engineered peptides for the development of actively tumor targeted liposomal carriers of doxorubicin. Cancer Lett. 2013;334(2): 284-292.

11. Lee BS, Yip AT, Thach AV, Rodriguez AR, Deming TJ, Kamei DT. The targeted delivery of doxorubicin with transferrin-conjugated block copolypeptide vesicles. Int J Pharm. 2015;496(2):903-911.

12. Jain K, Mehra NK, Jain NK. Potentials and emerging trends in nanopharmacology. Curr Opin Pharmacol. 2014;15:97-106.

13. Tomuleasa $\mathrm{C}$, Braicu C, Irimie A, Craciun L, Berindan-Neagoe I. Nanopharmacology in translational hematology and oncology. Int $J$ Nanomedicine. 2014;9:3465-3479.

14. Kim PS, Djazayeri S, Zeineldin R. Novel nanotechnology approaches to diagnosis and therapy of ovarian cancer. Gynecol Oncol. 2011; 120(3):393-403

15. Ajnai G, Chiu A, Kan T, Cheng CC, Tsai TH, Chang J. Trends of gold nanoparticle-based drug delivery system in cancer therapy. J Exp Clin Med. 2014;6(6):172-178.

16. Gao Y, Xie J, Chen H, et al. Nanotechnology-based intelligent drug design for cancer metastasis treatment. Biotechnol Adv. 2014;32(4): 761-777.

17. Song G, Tarrant TK, White TF, et al. Roles of chemokines CCL2 and CCL5 in the pharmacokinetics of PEGylated liposomal doxorubicin in vivo and in patients with recurrent epithelial ovarian cancer. Nanomedicine. 2015;11(7):1797-1807.

18. Wang Y, Chen L. Quantum dots, lighting up the research and development of nanomedicine. Nanomedicine. 2011;7(4):385-402.

19. Baetke SC, Lammers T, Kiessling F. Applications of nanoparticles for diagnosis and therapy of cancer. Br J Radiol. 2015;88(1054): 20150207.

20. Irimie AI, Braicu C, Cojocneanu-Petric R, Berindan-Neagoe I, Campian RS. Novel technologies for oral squamous carcinoma biomarkers in diagnostics and prognostics. Acta Odontol Scand. 2015;73(3): 161-168.
21. Thanh NTK, Green LAW. Functionalisation of nanoparticles for biomedical applications. Nano Today. 2010;5:213-230.

22. Petrushev B, Boca S, Simon T, et al. Gold nanoparticles enhance the effect of tyrosine kinase inhibitors in acute myeloid leukemia therapy. Int J Nanomedicine. 2016;11:641-660.

23. Nagy-Simon T, Tatar AS, Craciun AM, et al. Antibody conjugated, Raman tagged hollow gold-silver nanospheres for specific targeting and multimodal dark-field/SERS/two photon-FLIM imaging of CD19(+) B lymphoblasts. ACS Appl Mater Interfaces. 2017;9(25): 21155-21168.

24. Tatar AS, Nagy-Simon T, Tomuleasa C, Boca S, Astilean S. Nanomedicine approaches in acute lymphoblastic leukemia. J Control Release. 2016;238:123-138.

25. Suarasan S, Simon T, Boca S, Tomuleasa C, Astilean S. Gelatin-coated gold nanoparticles as carriers of FLT3 inhibitors for acute myeloid leukemia treatment. Chem Biol Drug Des. 2016;87(6):927-935.

26. Simon T, Tomuleasa C, Bojan A, Berindan-Neagoe I, Boca S, Astilean S. Design of FLT3 inhibitor - gold nanoparticle conjugates as potential therapeutic agents for the treatment of acute myeloid leukemia. Nanoscale Res Lett. 2015;10(1):466.

27. Ma Y, Fan X, Li L. pH-sensitive polymeric micelles formed by doxorubicin conjugated prodrugs for co-delivery of doxorubicin and paclitaxel. Carbohydr Polym. 2016;137:19-29.

28. Schilt Y, Berman T, Wei X, Barenholz Y, Raviv U. Using solution X-ray scattering to determine the high-resolution structure and morphology of PEGylated liposomal doxorubicin nanodrugs. Biochim Biophys Acta. 2016;1860(1 Pt A):108-119.

29. Shibata $\mathrm{H}$, Yoshida $\mathrm{H}$, Izutsu $\mathrm{K}$, et al. Interaction kinetics of serum proteins with liposomes and their effect on phospholipase-induced liposomal drug release. Int J Pharm. 2015;495(2):827-839.

30. Varkouhi AK, Scholte M, Storm G, Haisma HJ. Endosomal escape pathways for delivery of biologicals. J Control Release. 2011;151(3): 220-228.

31. Kou L, Sun J, Zhai Y, He Z. The endocytosis and intracellular fate of nanomedicines: implication for rational design. Asian J Pharm Sci. 2013; $8(1): 1-10$

32. Rascol E, Daurat M, Da Silva A, et al. Biological fate of $\mathrm{Fe}(3) \mathrm{O}(4)$ core-shell mesoporous silica nanoparticles depending on particle surface chemistry. Nanomaterials. 2017;7(7):162.

33. Peñaloza JP, Márquez-Miranda V, Cabana-Brunod M, et al. Intracellular trafficking and cellular uptake mechanism of PHBV nanoparticles for targeted delivery in epithelial cell lines. J Nanobiotechnology. 2017;15(1):1.

34. Morille M, Passirani C, Vonarbourg A, Clavreul A, Benoit JP. Progress in developing cationic vectors for non-viral systemic gene therapy against cancer. Biomaterials. 2008;29(24-25):3477-3496.

35. He CX, Tabata Y, Gao JQ. Non-viral gene delivery carrier and its three-dimensional transfection system. Int J Pharm. 2010;386(1-2):232-242.

36. Itaka K, Kataoka K. Recent development of nonviral gene delivery systems with virus-like structures and mechanisms. Eur J Pharm Biopharm. 2009;71(3):475-483.

37. Yang N. An overview of viral and nonviral delivery systems for microRNA. Int J Pharm Investig. 2015;5(4):179-181.

38. Lee JH, Kim Y, Yoon YE, et al. Development of efficient adenoassociated virus (AAV)-mediated gene delivery system with a phytoactive material for targeting human melanoma cells. $N$ Biotechnol. 2017;37(Pt B):194-199.

39. Elouahabi A, Ruysschaert JM. Formation and intracellular trafficking of lipoplexes and polyplexes. Mol Ther. 2005;11(3):336-347.

40. Riley MK, Vermerris W. Recent advances in nanomaterials for gene delivery-a review. Nanomaterials (Basel). 2017;7(5).

41. McErlean EM, McCrudden CM, McCarthy HO. Chapter 03: Multifunctional delivery systems for cancer gene therapy. In: Hashad D, editor. Gene Therapy - Principles and Challenges. Rijeka: InTech; 2015.

42. Ghosh R, Singh LC, Shohet JM, Gunaratne PH. A gold nanoparticle platform for the delivery of functional microRNAs into cancer cells. Biomaterials. 2013;34(3):807-816. 
43. Crew E, Tessel MA, Rahman S, et al. MicroRNA conjugated gold nanoparticles and cell transfection. Anal Chem. 2012;84(1): 26-29.

44. Berce C, Lucan C, Petrushev B, et al. In vivo assessment of bone marrow toxicity by gold nanoparticle-based bioconjugates in Crl:CD1(ICR) mice. Int J Nanomedicine. 2016;11:4261-4273.

45. Ekin A, Karatas OF, Culha M, Ozen M. Designing a gold nanoparticlebased nanocarrier for microRNA transfection into the prostate and breast cancer cells. J Gene Med. 2014;16(11-12):331-335.

46. Orza A, Soriţău O, Tomuleasa C, et al. Reversing chemoresistance of malignant glioma stem cells using gold nanoparticles. Int JNanomedicine. 2013;8:689-702.

47. Tomuleasa C, Soritau O, Orza A, et al. Gold nanoparticles conjugated with cisplatin/doxorubicin/capecitabine lower the chemoresistance of hepatocellular carcinoma-derived cancer cells. J Gastrointestin Liver Dis. 2012;21(2):187-196.

48. Tao L, Faig A, Uhrich KE. Liposomal stabilization using a sugarbased, PEGylated amphiphilic macromolecule. J Colloid Interface Sci. 2014;431:112-116.

49. Sugiyama I, Sadzuka Y. Enhanced antitumor activity of different double arms polyethyleneglycol-modified liposomal doxorubicin. Int J Pharm. 2013;441(1-2):279-284.

50. Beloglazova NV, Goryacheva OA, Speranskaya ES, et al. Silica-coated liposomes loaded with quantum dots as labels for multiplex fluorescent immunoassay. Talanta. 2015;134:120-125.

51. Bunker A. Poly(ethylene glycol) in drug delivery, why does it work, and can we do better? All atom molecular dynamics simulation provides some answers. Phys Procedia. 2012;34:24-33.

52. Danhier F, Feron O, Préat V. To exploit the tumor microenvironment: passive and active tumor targeting of nanocarriers for anti-cancer drug delivery. J Control Release. 2010;148(2):135-146.

53. Seguin J, Brullé L, Boyer R, et al. Liposomal encapsulation of the natural flavonoid fisetin improves bioavailability and antitumor efficacy. Int $J$ Pharm. 2013;444(1-2):146-154.

54. Shin GH, Kim JT, Park HJ. Recent developments in nanoformulations of lipophilic functional foods. Trends Food Sci Technol. 2015;46(1): 144-157.

55. Lee BK, Yun YH, Park K. Smart nanoparticles for drug delivery: boundaries and opportunities. Chem Eng Sci. 2015;125:158-164.

56. Refuerzo JS, Alexander JF, Leonard F, Leon M, Longo M, Godin B. Liposomes: a nanoscale drug carrying system to prevent indomethacin passage to the fetus in a pregnant mouse model. Am J Obstet Gynecol. 2015;212(4):508.e1-e7.

57. Wang TW, Yeh CW, Kuan CH, et al. Tailored design of multifunctional and programmable $\mathrm{pH}$-responsive self-assembling polypeptides as drug delivery nanocarrier for cancer therapy. Acta Biomater. 2017;58:54-66.

58. Constantinidou A, Jones RL, Scurr M, Al-Muderis O, Judson I. Pegylated liposomal doxorubicin, an effective, well-tolerated treatment for refractory aggressive fibromatosis. Eur J Cancer. 2009;45(17): 2930-2934.

59. Ananda S, Nowak AK, Cher L, et al. Phase 2 trial of temozolomide and pegylated liposomal doxorubicin in the treatment of patients with glioblastoma multiforme following concurrent radiotherapy and chemotherapy. J Clin Neurosci. 2011;18(11):1444-1448.

60. Liu C, Xu XY. A systematic study of temperature sensitive liposomal delivery of doxorubicin using a mathematical model. Comput Biol Med. 2015;60:107-116.

61. Rohlfing S, Aurich M, Schöning T, Ho AD, Witzens-Harig M. Nonpegylated liposomal doxorubicin as a component of R-CHOP is an effective and safe alternative to conventional doxorubicin in the treatment of patients with diffuse large B-cell lymphoma and preexisting cardiac diseases. Clin Lymphoma Myeloma Leuk. 2015;15(8):458-463.

62. Zhao Y, Alakhova DY, Kim JO, Bronich TK, Kabanov AV. A simple way to enhance Doxil ${ }^{\circledR}$ therapy: drug release from liposomes at the tumor site by amphiphilic block copolymer. J Control Release. 2013; 168(1):61-69.
63. Reynolds JG, Geretti E, Hendriks BS, et al. HER2-targeted liposomal doxorubicin displays enhanced anti-tumorigenic effects without associated cardiotoxicity. Toxicol Appl Pharmacol. 2012;262(1):1-10.

64. Prabhu RH, Patravale VB, Joshi MD. Polymeric nanoparticles for targeted treatment in oncology: current insights. Int J Nanomedicine. 2015; 10:1001-1018

65. Chavanpatil MD, Khdair A, Gerard B, et al. Surfactant-polymer nanoparticles overcome P-glycoprotein-mediated drug efflux. Mol Pharm. 2007;4(5):730-738.

66. Bellocq NC, Pun SH, Jensen GS, Davis ME. Transferrin-containing, cyclodextrin polymer-based particles for tumor-targeted gene delivery. Bioconjug Chem. 2003;14(6):1122-1132.

67. Wong HL, Rauth AM, Bendayan R, et al. A new polymer-lipid hybrid nanoparticle system increases cytotoxicity of doxorubicin against multidrug-resistant human breast cancer cells. Pharm Res. 2006; 23(7):1574-1585

68. Shmarakov I, Mukha I, Vityuk N, et al. Antitumor activity of alloy and core-shell-type bimetallic AgAu nanoparticles. Nanoscale Res Lett. 2017;12(1):333.

69. Fakhri A, Tahami S, Naji M. Synthesis and characterization of core-shell bimetallic nanoparticles for synergistic antimicrobial effect studies in combination with doxycycline on burn specific pathogens. J Photochem Photobiol B. 2017;169:21-26.

70. Mittal AK, Kumar S, Banerjee UC. Quercetin and gallic acid mediated synthesis of bimetallic (silver and selenium) nanoparticles and their antitumor and antimicrobial potential. J Colloid Interface Sci. 2014; 431:194-199.

71. Wu P, Gao Y, Zhang H, Cai C. Aptamer-guided silver-gold bimetallic nanostructures with highly active surface-enhanced Raman scattering for specific detection and near-infrared photothermal therapy of human breast cancer cells. Anal Chem. 2012;84(18):7692-7699.

72. Alshatwi AA, Athinarayanan J, Periasamy VS. Green synthesis of bimetallic Au@Pt nanostructures and their application for proliferation inhibition and apoptosis induction in human cervical cancer cell. J Mater Sci Mater Med. 2015;26(3):148.

73. Madaan K, Kumar S, Poonia N, Lather V, Pandita D. Dendrimers in drug delivery and targeting: drug-dendrimer interactions and toxicity issues. J Pharm Bioallied Sci. 2014;6(3):139-150.

74. Kesharwani P, Jain K, Jain NK. Dendrimer as nanocarrier for drug delivery. Prog Polym Sci. 2014;39(2):268-307.

75. Zhang W, Zhang Z, Zhang Y. The application of carbon nanotubes in target drug delivery systems for cancer therapies. Nanoscale Res Lett. 2011;6:555

76. Kushwaha SKS, Ghoshal S, Rai AK, Singh S. Carbon nanotubes as a novel drug delivery system for anticancer therapy: a review. Braz J Pharm Sci. 2013;49(4):629-643.

77. Gherman C, Tudor MC, Constantin B, et al. Pharmacokinetics evaluation of carbon nanotubes using FTIR analysis and histological analysis. J Nanosci Nanotechnol. 2015;15(4):2865-2869.

78. Farahani BV, Behbahani GR, Javadi N. Functionalized multi walled carbon nanotubes as a carrier for doxorubicin: drug adsorption study and statistical optimization of drug loading by factorial design methodology. J Braz Chem Soc. 2016;27(4):694-705.

79. Fletcher CDM, Bridge JA, Hogendoorn P, Mertens F. WHO Classification of Tumours of Soft Tissue and Bone. 4th ed. Lyon: IARC Press; 2013.

80. Dai M, Frezzo JA, Sharma E, et al. Engineered protein polymer-gold nanoparticle hybrid materials for small molecule delivery. J Nanomed Nanotechnol. 2016;7(1).

81. Dorsey JF, Sun L, Joh DY, et al. Gold nanoparticles in radiation research: potential applications for imaging and radiosensitization. Transl Cancer Res. 2013;2(4):280-291.

82. Zhang Y, Walker JB, Minic Z, Liu F, Goshgarian H, Mao G. Transporter protein and drug-conjugated gold nanoparticles capable of bypassing the blood-brain barrier. Sci Rep. 2016;6:25794.

83. Kouri FM, Hurley LA, Daniel WL, et al. miR-182 integrates apoptosis, growth, and differentiation programs in glioblastoma. Genes Dev. 2015; 29(7):732-745. 
84. Gehrmann MK, Kimm MA, Stangl S, et al. Imaging of Hsp70-positive tumors with cmHsp70.1 antibody-conjugated gold nanoparticles. Int J Nanomedicine. 2015;10:5687-5700.

85. Dreaden EC, Austin LA, Mackey MA, El-Sayed MA. Size matters: gold nanoparticles in targeted cancer drug delivery. Ther Deliv. 2012; 3(4):457-478.

86. Jiang Y, Tang R, Duncan B, et al. Direct cytosolic delivery of siRNA using nanoparticle-stabilized nanocapsules. Angew Chem Int Ed Engl. 2015;54(2):506-510.

87. Mamot C, Drummond DC, Noble CO, et al. Epidermal growth factor receptor-targeted immunoliposomes significantly enhance the efficacy of multiple anticancer drugs in vivo. Cancer Res. 2005;65(24): 11631-11638.

88. Kirpotin DB, Drummond DC, Shao Y, et al. Antibody targeting of long-circulating lipidic nanoparticles does not increase tumor localization but does increase internalization in animal models. Cancer Res. 2006;66(13):6732-6740.

89. Yamada A, Taniguchi Y, Kawano K, Honda T, Hattori Y, Maitani Y. Design of folate-linked liposomal doxorubicin to its antitumor effect in mice. Clin Cancer Res. 2008;14(24):8161-8168.

90. ElBayoumi TA, Torchilin VP. Tumor-targeted nanomedicines: enhanced antitumor efficacy in vivo of doxorubicin-loaded, longcirculating liposomes modified with cancer-specific monoclonal antibody. Clin Cancer Res. 2009;15(6):1973-1980.

91. Elbayoumi TA, Torchilin VP. Enhanced cytotoxicity of monoclonal anticancer antibody 2C5-modified doxorubicin-loaded PEGylated liposomes against various tumor cell lines. Eur J Pharm Sci. 2007;32(3): 159-168.

92. Yang T, Choi MK, Cui FD, et al. Antitumor effect of paclitaxel-loaded PEGylated immunoliposomes against human breast cancer cells. Pharm Res. 2007;24(12):2402-2411.

93. Cline EN, Li MH, Choi SK, et al. Paclitaxel-conjugated PAMAM dendrimers adversely affect microtubule structure through two independent modes of action. Biomacromolecules. 2013;14(3): 654-664.

94. Kulhari H, Pooja D, Shrivastava S, et al. Trastuzumab-grafted PAMAM dendrimers for the selective delivery of anticancer drugs to HER2-positive breast cancer. Sci Rep. 2016;6:23179.

95. Lee SJ, Jeong YI, Park HK, et al. Enzyme-responsive doxorubicin release from dendrimer nanoparticles for anticancer drug delivery. Int J Nanomedicine. 2015;10:5489-5503.

96. Sobhani Z, Dinarvand R, Atyabi F, Ghahremani M, Adeli M. Increased paclitaxel cytotoxicity against cancer cell lines using a novel functionalized carbon nanotube. Int J Nanomedicine. 2011;6:705-719.

97. Liu Z, Fan AC, Rakhra K, et al. Supramolecular stacking of doxorubicin on carbon nanotubes for in vivo cancer therapy. Angew Chem Int Ed Engl. 2009;48(41):7668-7672.

98. Marqués-Gallego P, de Kroon AI. Ligation strategies for targeting liposomal nanocarriers. Biomed Res Int. 2014;2014:129458.

99. Mout R, Moyano DF, Rana S, Rotello VM. Surface functionalization of nanoparticles for nanomedicine. Chem Soc Rev. 2012;41(7): 2539-2544.

100. Chen F, Goel S, Valdovinos HF, et al. In vivo integrity and biological fate of chelator-free zirconium-89-labeled mesoporous silica nanoparticles. ACS Nano. 2015;9(8):7950-7959.

101. Morse DL, Hostetter G, Balagurunathan Y, Gillies RJ, Han H. Identification of pancreatic cancer-specific cell-surface markers for development of targeting ligands. Methods Mol Biol. 2010;624: $195-210$

102. Karsten U, Goletz S. What makes cancer stem cell markers different? Springerplus. 2013;2(1):301.

103. Ghosh R, Dey J. Aggregation behavior of poly(ethylene glycol) chaincontaining anionic amphiphiles: thermodynamic, spectroscopic and microscopic studies. J Colloid Interface Sci. 2015;451:53-62.

104. Sanyakamdhorn S, Bekale L, Agudelo D, Tajmir-Riahi HA. Structural analysis of doxorubicin-polymer conjugates. Colloids Surf B Biointerfaces. 2015;135:175-182.
105. Adati RD, Feitosa E. The assembly of dialkyldimethylammonium bromide cationic lipids as vesicles or monolayers in presence of poly(ethylene glycol). Thermochim Acta. 2015;613:71-76.

106. Zhang C, Wang L, Zhai T, Wang X, Dan Y, Turng LS. The surface grafting of graphene oxide with poly(ethylene glycol) as a reinforcement for poly(lactic acid) nanocomposite scaffolds for potential tissue engineering applications. J Mech Behav Biomed Mater. 2016;53:403-413.

107. Zhao D, Yu S, Liu G, Yuan Q, Guo H. Polypiperazine-amide nanofiltration membrane incorporated with poly(ethylene glycol) derivative for electrodialysis concentrate treatment. Sep Purif Technol. 2015; 153:43-50

108. Zafarani-Moattar MT, Shekaari H, Jafari P, Hosseinzadeh M. The effect of temperature and molar mass on the (liquid + liquid) equilibria of (poly ethylene glycol dimethyl ether + di-sodium hydrogen citrate + water) systems: experimental and correlation. J Chem Thermodyn. 2015;91:435-444

109. Biswas S, Deshpande PP, Perche F, Dodwadkar NS, Sane SD, Torchilin VP. Octa-arginine-modified pegylated liposomal doxorubicin: an effective treatment strategy for non-small cell lung cancer. Cancer Lett. 2013;335(1):191-200.

110. Shaffer DL, Jaramillo H, Castrillón SRV, Lu X, Elimelech M. Post-fabrication modification of forward osmosis membranes with a poly(ethylene glycol) block copolymer for improved organic fouling resistance. J Membr Sci. 2015;490:209-219.

111. Wu Y, Zhang Y, Zhang W, Sun C, Wu J, Tang J. Reversing of multidrug resistance breast cancer by co-delivery of P-gp siRNA and doxorubicin via folic acid-modified core-shell nanomicelles. Colloids Surf B Biointerfaces. 2016;138:60-69.

112. Varga Z, Mihály J, Berényi S, Bóta A. Structural characterization of the poly(ethylene glycol) layer of sterically stabilized liposomes by means of FTIR spectroscopy. Eur Polym J. 2013;49(9):2415-2421.

113. Martin AL, Bernas LM, Rutt BK, Foster PJ, Gillies ER. Enhanced cell uptake of superparamagnetic iron oxide nanoparticles functionalized with dendritic guanidines. Bioconjug Chem. 2008;19(12):2375-2384.

114. Bharali DJ, Klejbor I, Stachowiak EK, et al. Organically modified silica nanoparticles: a nonviral vector for in vivo gene delivery and expression in the brain. Proc Natl Acad Sci U S A. 2005;102(32): 11539-11544.

115. Park SJ, Taton TA, Mirkin CA. Array-based electrical detection of DNA with nanoparticle probes. Science. 2002;295(5559):1503-1506.

116. Seferos DS, Giljohann DA, Hill HD, Prigodich AE, Mirkin CA. Nano-flares: probes for transfection and mRNA detection in living cells. J Am Chem Soc. 2007;129(50):15477-15479.

117. Hao R, Xing R, Xu Z, Hou Y, Gao S, Sun S. Synthesis, functionalization, and biomedical applications of multifunctional magnetic nanoparticles. Adv Mater. 2010;22(25):2729-2742.

118. Hatakeyama H, Akita H, Harashima $H$. The polyethyleneglycol dilemma: advantage and disadvantage of PEGylation of liposomes for systemic genes and nucleic acids delivery to tumors. Biol Pharm Bull. 2013;36(6):892-899.

119. Mishra P, Nayak B, Dey RK. PEGylation in anti-cancer therapy: an overview. Asian J Pharm Sci. 2016;11(3):337-348.

120. Durymanov MO, Rosenkranz AA, Sobolev AS. Current approaches for improving intratumoral accumulation and distribution of nanomedicines. Theranostics. 2015;5(9):1007-1020.

121. Veronese FM, Pasut G. PEGylation, successful approach to drug delivery. Drug Discov Today. 2005;10(21):1451-1458.

122. Shang L, Nienhaus K, Nienhaus GU. Engineered nanoparticles interacting with cells: size matters. J Nanobiotechnology. 2014;12:5.

123. Lee H, Fonge H, Hoang B, Reilly RM, Allen C. The effects of particle size and molecular targeting on the intratumoral and subcellular distribution of polymeric nanoparticles. Mol Pharm. 2010;7(4): 1195-1208.

124. Nel AE, Mädler L, Velegol D, et al. Understanding biophysicochemical interactions at the nano-bio interface. Nat Mater. 2009;8(7): 543-557. 
125. Spencer DS, Puranik AS, Peppas NA. Intelligent nanoparticles for advanced drug delivery in cancer treatment. Curr Opin Chem Eng. 2015;7:84-92.

126. Chen X, Liu L, Jiang C. Charge-reversal nanoparticles: novel targeted drug delivery carriers. Acta Pharm Sin B. 2016;6(4):261-267.

127. He C, Hu Y, Yin L, Tang C, Yin C. Effects of particle size and surface charge on cellular uptake and biodistribution of polymeric nanoparticles. Biomaterials. 2010;31(13):3657-3666.

128. Xiao K, Li Y, Luo J, et al. The effect of surface charge on in vivo biodistribution of PEG-oligocholic acid based micellar nanoparticles. Biomaterials. 2011;32(13):3435-3446.

129. Goodman CM, McCusker CD, Yilmaz T, Rotello VM. Toxicity of gold nanoparticles functionalized with cationic and anionic side chains. Bioconjug Chem. 2004;15(4):897-900.

130. Natarajan JV, Nugraha C, Ng XW, Venkatraman S. Sustainedrelease from nanocarriers: a review. J Control Release. 2014;193: $122-138$.

131. Smith BR, Kempen P, Bouley D, et al. Shape matters: intravital microscopy reveals surprising geometrical dependence for nanoparticles in tumor models of extravasation. Nano Lett. 2012;12(7): 3369-3377.

132. Yin PT, Shah BP, Lee KB. Combined magnetic nanoparticle-based microRNA and hyperthermia therapy to enhance apoptosis in brain cancer cells. Small. 2014;10(20):4106-4112.

133. Schwerdt A, Zintchenko A, Concia M, et al. Hyperthermia-induced targeting of thermosensitive gene carriers to tumors. Hum Gene Ther. 2008;19(11):1283-1292.

134. Zhang Z, Liu Y, Jarreau C, Welch MJ, Taylor JS. Nucleic acid-directed self-assembly of multifunctional gold nanoparticle imaging agents. Biomater Sci. 2013;1(10):1055-1064.

135. Kamendi H, Zhou Y, Crosby M, et al. Doxorubicin: comparison between 3-h continuous and bolus intravenous administration paradigms on cardio-renal axis, mitochondrial sphingolipids and pathology. Toxicol Appl Pharmacol. 2015;289(3):560-572.

136. Soininen SK, Repo JK, Karttunen V, Auriola S, Vähäkangas KH, Ruponen M. Human placental cell and tissue uptake of doxorubicin and its liposomal formulations. Toxicol Lett. 2015;239(2): $108-114$.

137. Zakaria S, Gamal-Eldeen AM, El-Daly SM, Saleh S. Synergistic apoptotic effect of Doxil ${ }^{\circledR}$ and aminolevulinic acid-based photodynamic therapy on human breast adenocarcinoma cells. Photodiagnosis Photodyn Ther. 2014;11(2):227-238.

138. Rose PG, Blessing JA, Lele S, Abulafia O. Evaluation of pegylated liposomal doxorubicin (Doxil) as second-line chemotherapy of squamous cell carcinoma of the cervix: a phase II study of the Gynecologic Oncology Group. Gynecol Oncol. 2006;102(2):210-213.

139. Dellapasqua S, Mazza M, Rosa D, et al. Pegylated liposomal doxorubicin in combination with low-dose metronomic cyclophosphamide as preoperative treatment for patients with locally advanced breast cancer. Breast. 2011;20(4):319-323.

140. Yang X, Gao H, Qian F, Zhao C, Liao X. Internal standard method for the measurement of doxorubicin and daunorubicin by capillary electrophoresis with in-column double optical-fiber LED-induced fluorescence detection. J Pharm Biomed Anal. 2016;117:118-124.

141. Koh JS, Yi CO, Heo RW, et al. Protective effect of cilostazol against doxorubicin-induced cardiomyopathy in mice. Free Radic Biol Med. 2015;89:54-61.

142. Niu J, Xue A, Chi Y, et al. Induction of miRNA-181a by genotoxic treatments promotes chemotherapeutic resistance and metastasis in breast cancer. Oncogene. 2016;35(10):1302-1313.

143. Wang Y, Mei X, Yuan J, Lu W, Li B, Xu D. Taurine zinc solid dispersions attenuate doxorubicin-induced hepatotoxicity and cardiotoxicity in rats. Toxicol Appl Pharmacol. 2015;289(1):1-11.

144. Mohammadi ZA, Aghamiri SF, Zarrabi A, Talaie MR. A comparative study on non-covalent functionalization of carbon nanotubes by chitosan and its derivatives for delivery of doxorubicin. Chem Phys Lett. 2015;642:22-28.
145. Adwas AA, Elkhoely AA, Kabel AM, Abdel-Rahman MN, Eissa AA. Anti-cancer and cardioprotective effects of indol-3-carbinol in doxorubicin-treated mice. J Infect Chemother. 2016;22(1):36-43.

146. Oki Y, Ewer MS, Lenihan DJ, et al. Pegylated liposomal doxorubicin replacing conventional doxorubicin in standard R-CHOP chemotherapy for elderly patients with diffuse large B-cell lymphoma: an open label, single arm, phase II trial. Clin Lymphoma Myeloma Leuk. 2015;15(3):152-158.

147. Rios-Doria J, Durham N, Wetzel L, et al. Doxil synergizes with cancer immunotherapies to enhance antitumor responses in syngeneic mouse models. Neoplasia. 2015;17(8):661-670.

148. Zhang P, Li J, Ghazwani M, et al. Effective co-delivery of doxorubicin and dasatinib using a PEG-Fmoc nanocarrier for combination cancer chemotherapy. Biomaterials. 2015;67:104-114.

149. Bandekar A, Karve S, Chang MY, Mu Q, Rotolo J, Sofou S. Antitumor efficacy following the intracellular and interstitial release of liposomal doxorubicin. Biomaterials. 2012;33(17):4345-4352.

150. Kopecka J, Campia I, Olivero P, et al. A LDL-masked liposomaldoxorubicin reverses drug resistance in human cancer cells. J Control Release. 2011;149(2):196-205.

151. Soundararajan A, Bao A, Phillips WT, Perez R 3rd, Goins BA. [(186)Re]Liposomal doxorubicin (Doxil): in vitro stability, pharmacokinetics, imaging and biodistribution in a head and neck squamous cell carcinoma xenograft model. Nucl Med Biol. 2009;36(5): 515-524.

152. Yokoi K, Chan D, Kojic M, et al. Liposomal doxorubicin extravasation controlled by phenotype-specific transport properties of tumor microenvironment and vascular barrier. J Control Release. 2015; 217:293-299.

153. Ko EM, Lippmann Q, Caron WP, Zamboni W, Gehrig PA. Clinical risk factors of PEGylated liposomal doxorubicin induced palmar plantar erythrodysesthesia in recurrent ovarian cancer patients. Gynecol Oncol. 2013;131(3):683-688.

154. Kushnir CL, Angarita AM, Havrilesky LJ, et al. Selective cardiac surveillance in patients with gynecologic cancer undergoing treatment with pegylated liposomal doxorubicin (PLD). Gynecol Oncol. 2015; 137(3):503-507.

155. Gill SE, Savage K, Wysham WZ, Blackhurst DW, Winter WE, Puls LE. Continuing routine cardiac surveillance in long-term use of pegylated liposomal doxorubicin: is it necessary? Gynecol Oncol. 2013;129(3):544-547.

156. Jansson MD, Lund AH. MicroRNA and cancer. Mol Oncol. 2012; 6(6):590-610.

157. Reddy KB. MicroRNA (miRNA) in cancer. Cancer Cell Int. 2015; $15: 38$.

158. Braicu C, Cojocneanu-Petric R, Chira S, et al. Clinical and pathological implications of miRNA in bladder cancer. Int $J$ Nanomedicine. 2015; 10:791-800.

159. Berindan-Neagoe I, Calin GA. Molecular pathways: microRNAs, cancer cells, and microenvironment. Clin Cancer Res. 2014;20(24): 6247-6253.

160. Geng Y, Lin D, Shao L, Yan F, Ju H. Cellular delivery of quantum dotbound hybridization probe for detection of intracellular pre-microRNA using chitosan/poly $(\gamma$-glutamic acid) complex as a carrier. PLoS One. 2013;8(6):e65540.

161. Zaharie F, Muresan MS, Petrushev B, et al. Exosome-carried microRNA-375 inhibits cell progression and dissemination via Bcl-2 blocking in colon cancer. J Gastrointestin Liver Dis. 2015;24(4): 435-443.

162. Grewal R, Cucuianu A, Swanepoel C, et al. The role of microRNAs in the pathogenesis of HIV-related lymphomas. Crit Rev Clin Lab Sci. 2015;52(5):232-241.

163. Muresan M, Zaharie F, Bojan A, et al. MicroRNAs in liver malignancies. Basic science applied in surgery. J BUON. 2015;20(2):361-375.

164. Braicu C, Tomuleasa C, Monroig P, Cucuianu A, Berindan-Neagoe I, Calin GA. Exosomes as divine messengers: are they the Hermes of modern molecular oncology? Cell Death Differ. 2015;22(1):34-45. 
165. Kim JH, Yeom JH, Ko JJ, et al. Effective delivery of anti-miRNA DNA oligonucleotides by functionalized gold nanoparticles. J Biotechnol. 2011;155(3):287-292.

166. Wu Y, Crawford M, Mao Y, et al. Therapeutic delivery of microRNA$29 \mathrm{~b}$ by cationic lipoplexes for lung cancer. Mol Ther Nucleic Acids. 2013;2:e84.

167. Wu Y, Crawford M, Yu B, Mao Y, Nana-Sinkam SP, Lee LJ. MicroRNA delivery by cationic lipoplexes for lung cancer therapy. Mol Pharm. 2011;8(4):1381-1389.

168. Pramanik D, Campbell NR, Karikari C, et al. Restitution of tumor suppressor microRNAs using a systemic nanovector inhibits pancreatic cancer growth in mice. Mol Cancer Ther. 2011;10(8):1470-1480.

169. Anand S, Majeti BK, Acevedo LM, et al. MicroRNA-132-mediated loss of p120RasGAP activates the endothelium to facilitate pathological angiogenesis. Nat Med. 2010;16(8):909-914.

170. Craig VJ, Tzankov A, Flori M, Schmid CA, Bader AG, Müller A. Systemic microRNA-34a delivery induces apoptosis and abrogates growth of diffuse large B-cell lymphoma in vivo. Leukemia. 2012; 26(11):2421-2424.

171. Wiggins JF, Ruffino L, Kelnar K, et al. Development of a lung cancer therapeutic based on the tumor suppressor microRNA-34. Cancer Res. 2010;70(14):5923-5930.

172. Trang P, Wiggins JF, Daige CL, et al. Systemic delivery of tumor suppressor microRNA mimics using a neutral lipid emulsion inhibits lung tumors in mice. Mol Ther. 2011;19(6):1116-1122.

173. Liu C, Kelnar K, Liu B, et al. The microRNA miR-34a inhibits prostate cancer stem cells and metastasis by directly repressing CD44. Nat Med. 2011;17(2):211-215.

174. Zhang M, Zhou X, Wang B, et al. Lactosylated gramicidin-based lipid nanoparticles (Lac-GLN) for targeted delivery of anti-miR155 to hepatocellular carcinoma. J Control Release. 2013;168(3): 251-261.

175. Chen Y, Zhu X, Zhang X, Liu B, Huang L. Nanoparticles modified with tumor-targeting $\mathrm{scFv}$ deliver siRNA and miRNA for cancer therapy. Mol Ther. 2010;18(9):1650-1656.

176. Liu XQ, Song WJ, Sun TM, Zhang PZ, Wang J. Targeted delivery of antisense inhibitor of miRNA for antiangiogenesis therapy using cRGD-functionalized nanoparticles. Mol Pharm. 2011;8(1): 250-259.

177. Chiou GY, Cherng JY, Hsu HS, et al. Cationic polyurethanes-short branch PEI-mediated delivery of Mir145 inhibited epithelial-mesenchymal transdifferentiation and cancer stem-like properties and in lung adenocarcinoma. J Control Release. 2012;159(2):240-250.

178. Hu QL, Jiang QY, Jin X, et al. Cationic microRNA-delivering nanovectors with bifunctional peptides for efficient treatment of PANC-1 xenograft model. Biomaterials. 2013;34(9):2265-2276.

179. Ren Y, Kang CS, Yuan XB, et al. Co-delivery of as-miR-21 and 5-FU by poly(amidoamine) dendrimer attenuates human glioma cell growth in vitro. J Biomater Sci Polym Ed. 2010;21(3):303-314.
180. Babar IA, Cheng CJ, Booth CJ, et al. Nanoparticle-based therapy in an in vivo microRNA-155 (miR-155)-dependent mouse model of lymphoma. Proc Natl Acad Sci U S A. 2012;109(26):E1695-E1704.

181. Tivnan A, Orr WS, Gubala V, et al. Inhibition of neuroblastoma tumor growth by targeted delivery of microRNA-34a using antidisialoganglioside GD2 coated nanoparticles. PLoS One. 2012; 7(5):e38129.

182. Kim JK, Choi KJ, Lee M, Jo MH, Kim S. Molecular imaging of a cancer-targeting theragnostics probe using a nucleolin aptamerand microRNA-221 molecular beacon-conjugated nanoparticle. Biomaterials. 2012;33(1):207-217.

183. Li L, Zhou L, Li Y, Lin S, Tomuleasa C. MicroRNA-21 stimulates gastric cancer growth and invasion by inhibiting the tumor suppressor effects of programmed cell death protein 4 and phosphatase and tensin homolog. J BUON. 2014;19(1):228-236.

184. Ben-Shushan D, Markovsky E, Gibori H, Tiram G, Scomparin A, Satchi-Fainaro R. Overcoming obstacles in microRNA delivery towards improved cancer therapy. Drug Deliv Transl Res. 2014;4(1):38-49.

185. Irimie AI, Braicu C, Pileczki V, et al. Knocking down of p53 triggers apoptosis and autophagy, concomitantly with inhibition of migration on SSC-4 oral squamous carcinoma cells. Mol Cell Biochem. 2016;419(1-2):75-82.

186. Lam JK, Chow MY, Zhang Y, Leung SW. siRNA versus miRNA as therapeutics for gene silencing. Mol Ther Nucleic Acids. 2015; 4:e252.

187. Guo W, Chen W, Yu W, Huang W, Deng W. Small interfering RNAbased molecular therapy of cancers. Chin J Cancer. 2013;32(9): $488-493$.

188. Son KH, Hong JH, Lee JW. Carbon nanotubes as cancer therapeutic carriers and mediators. Int J Nanomedicine. 2016;11:5163-5185.

189. Mack GS. MicroRNA gets down to business. Nat Biotechnol. 2007; 25(6):631-638.

190. Kalos M, Levine BL, Porter DL, et al. T cells with chimeric antigen receptors have potent antitumor effects and can establish memory in patients with advanced leukemia. Sci Transl Med. 2011; 3(95):95ra73.

191. Imai C, Mihara K, Andreansky M, et al. Chimeric receptors with 4-1BB signaling capacity provoke potent cytotoxicity against acute lymphoblastic leukemia. Leukemia. 2004;18(4):676-684.

192. Porter DL, Levine BL, Kalos M, Bagg A, June CH. Chimeric antigen receptor-modified T cells in chronic lymphoid leukemia. $N$ Engl J Med. 2011;365(8):725-733.

193. Tomuleasa C, Fuji S, Cucuianu A, et al. MicroRNAs as biomarkers for graft-versus-host disease following allogeneic stem cell transplantation. Ann Hematol. 2015;94(7):1081-1092.

194. Perica K, Varela JC, Oelke M, Schneck J. Adoptive T cell immunotherapy for cancer. Rambam Maimonides Med J. 2015;6(1):e0004.

195. Pardoll DM. The blockade of immune checkpoints in cancer immunotherapy. Nat Rev Cancer. 2012;12(4):252-264.
Drug Design, Development and Therapy

\section{Publish your work in this journal}

Drug Design, Development and Therapy is an international, peerreviewed open-access journal that spans the spectrum of drug design and development through to clinical applications. Clinical outcomes, patient safety, and programs for the development and effective, safe, and sustained use of medicines are the features of the journal, which

\section{Dovepress}

has also been accepted for indexing on PubMed Central. The manuscript management system is completely online and includes a very quick and fair peer-review system, which is all easy to use. Visit http://www.dovepress.com/testimonials.php to read real quotes from published authors. 